\title{
A comprehensive review of the pharmacodynamics, pharmacokinetics, and clinical effects of the neutral endopeptidase inhibitor racecadotril
}

\author{
Marion Eberlin ${ }^{1}$,Tobias Mück ${ }^{1}$ and Martin C. Michel ${ }^{2 *}$ \\ ${ }^{1}$ Department of Medical Affairs Germany, Boehringer Ingelheim Pharma GmbH \& Co KG, Ingelheim, Germany \\ 2 Department of Clinical Development and Medical Affairs, Boehringer Ingelheim Pharma GmbH \& Co KG, Ingelheim, Germany
}

Edited by:

Angelo A. Izzo, University of Naples

Federico II, Italy

\section{Reviewed by:}

Hemant Kulkarni, Texas Biomedical

Research Institute, USA

Luca Gallelli, School of Medicine

University of Catanzaro, Italy

\section{*Correspondence:}

Martin C. Michel, Department of Clinical Development and Medical Affairs, Boehringer Ingelheim Pharma Gmbh \& Co KG, Binger Str. 173,

55216 Ingelheim, Germany.

e-mail:martin.michel@

boehringer-ingelheim.com
Racecadotril, via its active metabolite thiorphan, is an inhibitor of the enzyme neutral endopeptidase (NEP, EC 3.4.24.11), thereby increasing exposure to NEP substrates including enkephalins and atrial natriuretic peptide (ANP). Upon oral administration racecadotril is rapidly and effectively converted into the active metabolite thiorphan, which does not cross the blood-brain-barrier. Racecadotril has mainly been tested in animal models and patients of three therapeutic areas. As an analgesic the effects of racecadotril across animal models were inconsistent. In cardiovascular diseases such as hypertension or congestive heart failure results from animal studies were promising, probably related to increased exposure to ANP, but clinical results have not shown substantial therapeutic benefit over existing treatment options in cardiovascular disease. In contrast, racecadotril was consistently effective in animal models and patients with various forms of acute diarrhea by inhibiting pathologic (but not basal) secretion from the gut without changing gastro-intestinal transit time or motility. This included studies in both adults and children. In direct comparative studies with loperamide in adults and children, racecadotril was at least as effective but exhibited fewer adverse events in most studies, particularly less rebound constipation. Several guidelines recommend the use of racecadotril as addition to oral rehydration treatment in children with acute diarrhea.

Keywords: racecadotril, neutral endopeptidase, analgesia, hypertension, congestive heart failure, diarrhea, loperamide

\section{BACKGROUND}

Acute diarrhea is an alteration of normal bowel movements characterized by an increase in the water content, volume, or frequency of stools. The most common causes are bacterial and viral infections, particularly rotavirus infections, but the specific spectrum of infectious agents depends on the clinical setting (Farthing, 2000). Such infections cause intestinal hypersecretion leading to fluid loss and dehydration. Accordingly, oral rehydration is the cornerstone of treatment, and a standardized glucose-electrolyte solution has been developed under the auspices of the World Health Organization and is being used with great success. While this has significantly improved the prognosis of acute diarrhea, it remains a clinical problem in both the developing world and in industrialized countries and, particularly in developing countries, acute diarrhea is still responsible for the death of two to three million individuals per year worldwide (Farthing, 2006).

While the infection underlying acute diarrhea typically is selflimiting, the associated dehydration can be life-threatening, particularly in children or the elderly. Moreover, a shortening of the duration of acute diarrhea can also be an important medical

Abbreviations: ANP, atrial natriuretic peptide; i.c.v., intra-cerebroventricular; i.p., intra-peritoneal; i.v., intravenous; NEP, neutral endopeptidase. aim. Therefore, drug treatment can also be a relevant part of the therapeutic approach, in most cases given on top of rehydration treatment. Among anti-diarrhea drugs antibiotics are typically limited to severe cases and other special situations. More frequently, $\mu$-opioid receptor agonists such as codeine, loperamide, and morphine are being employed, among which loperamide has become most frequently used (Baldi et al., 2009). Their main mechanism of action is a reduction of gut motility and accordingly they can cause secondary constipation, abdominal pain, and abdominal distension.

Against this background, racecadotril has been developed as a possible alternative to the use of $\mu$-opioid receptor agonists. Following its original registration as a prescription drug in France in 1992 it meanwhile is available in many countries around the globe, and since 2005 in some of them as a non-prescription drug. The present manuscript reviews the pharmacodynamic, pharmacokinetic, and clinical data for racecadotril and its active metabolite thiorphan. While the clinical focus of the manuscript is on the role of racecadotril in the treatment of diarrhea, we will also discuss other potential uses as they will aid the understanding of the overall clinical profile of the drug. Racecadotril has been reviewed in the past (Lecomte, 2000; Matheson and Noble, 2000; Schwartz, 2000) but those articles had a more limited scope and more than 40 new studies have been published since. 


\section{MOLECULAR EFFECTS OF RACECADOTRIL}

Racecadotril, formerly known as acetorphan, is a prodrug, which is converted to the active metabolite thiorphan (see below; Figure 1). Acetyl-thiorphan is another active metabolite of racecadotril but yields only low potency NEP inhibition (Lambert et al., 1993). Racecadotril has stereoisomers, and the $S$ - and $R$-isomers of racecadotril are named ecadotril (also known as BP102 or as sinorphan) and retorphan, respectively (Lecomte et al., 1990). Thus, in the subsequent text racecadotril and thiorphan refer to the racemate, whereas ecadotril refers to the $S$-isomer of racecadotril.

At the molecular level racecadotril and thiorphan act by inhibiting the enzyme neutral endopeptidase (NEP, EC 3.4.24.11; see below), which is a membrane-metalloendopeptidase also known as enkephalinase. NEP has various substrates including enkephalins (hence the name enkephalinase) but also atrial natriuretic peptide (ANP), brain natriuretic peptide, substance $\mathrm{P}$, neurotensins, and neuropeptide Y (van Kemmel et al., 1996; Turvill and Farthing, 1997). Therefore, NEP inhibition can potentially affect any of these mediators and observed in vivo effects in different organ systems may not always relate to the same enzyme substrate (see below).

The first report on thiorphan described an $\mathrm{IC}_{50}$ of $4.7 \mathrm{nM}$ for NEP inhibition in striatal membranes (Roques et al., 1980). Inhibition of purified NEP activity from mouse brain yielded affinity estimates ( $K_{\mathrm{i}}$ values) of 6.1 and $4500 \mathrm{nM}$ for thiorphan and racecadotril, respectively; however, when racecadotril was preincubated with rat brain membranes for $15 \mathrm{~min}$, an apparent $K_{\mathrm{i}}$ value of $8.6 \mathrm{nM}$ was observed, probably reflecting rapid in vitro conversion to thiorphan (Lecomte et al., 1986). A similar study reported an $\mathrm{IC}_{50}$ of $1.8 \mathrm{nM}$ for thiorphan with racecadotril being 1000 times less potent and acetyl-thiorphan having a value of $316 \mathrm{nM}$ (Lambert et al., 1993, 1995). For in vitro inhibition of rat kidney NEP an $\mathrm{IC}_{50}$ of $5.4 \mathrm{nM}$ was reported (Fink et al., 1995), apparently reflecting in vitro conversion to thiorphan as shown before in rat brain (Lecomte et al., 1986).

A second approach to assess thiorphan affinity for NEP has been radioligand binding studies. In saturation binding studies in various mouse tissues $\left[{ }^{3} \mathrm{H}\right]$-thiorphan exhibited an affinity $\left(\mathrm{K}_{\mathrm{d}}\right.$ value) of $0.46-0.77 \mathrm{nM}$, and the density of $\left[{ }^{3} \mathrm{H}\right]$-thiorphan binding sites was well correlated with measured NEP activity in a panel of 11 different mouse tissues (de la Baume et al., 1988). Similar saturation binding experiments using $\left[{ }^{3} \mathrm{H}\right]$-racecadotril as the ligand reported an affinity of $4-5 \mathrm{nM}$ in rats (Fournet-Bourguignon et al., 1992), apparently reflecting conversion of racecadotril to thiorphan in the assay (Lecomte et al., 1986). A third approach has been to measure occurrence of enkephalin break-down products such as the tripeptide Tyr-Gly-Gly, and in isolated rat brain slices this has yielded an $\mathrm{IC}_{50}$ of $9 \mathrm{nM}$ for thiorphan (Giros et al., 1986).

Correspondingly, it has repeatedly been observed that oral, intra-peritoneal (i.p.), or intravenous (i.v.) administration of racecadotril or ecadotril leads to a rapid reduction in NEP activity in plasma (Spillantini et al., 1986; Lecomte et al., 1990; Dussaule et al., 1991, 1993; Stasch et al., 1996; Duncan et al., 1999; Lecomte, 2000), kidney (Gros et al., 1989), and brain (Lecomte et al., 1986; Spillantini et al., 1986). Such studies were performed with consistent results in rats (Lecomte et al., 1986; Stasch et al., 1996; Wegner et al., 1996; Duncan et al., 1999), mice (Lecomte et al., 1986), and humans (Spillantini et al., 1986; Gros et al., 1989; Lecomte et al., 1990; Dussaule et al., 1991, 1993; Lecomte, 2000). In vivo inhibition of enkephaline metabolite formation was also observed in rat spinal cord after i.v. racecadotril (Llorens-Cortes et al., 1989) or in mouse striatum after intra-cerebro-ventricular (i.c.v.) thiorphan (Llorens-Cortes et al., 1986). Of note, assessment of NEP inhibition by measuring endogenous enkephalins can yield false negative results as enkephalines can also be metabolized by other aminopeptidases such as EC 3.4.11.2, and this can compensate for NEP inhibition (Bourgoin et al., 1986; Llorens-Cortes et al., 1986). As ANP also is a NEP substrate, NEP inhibition can also be assessed by changes of ANP concentrations in plasma and urine, which are described in detail in Section "Cardiovascular Studies."

The $R$ - and $S$-stereoisomers of thiorphan inhibited purified NEP activity with similar potency 1.7 vs. $2.2 \mathrm{nM}$, respectively, and occurrence of the enkephalin metabolite Tyr-Gly-Gly with an $\mathrm{IC}_{50}$ of $10 \mathrm{nM}$ (Giros et al., 1987). In the same study occurrence of Tyr-Gly-Gly in mouse striatum was also inhibited with similar potency by i.v. administration of ecadotril and retorphan, the stereoisomers of racecadotril $\left(\mathrm{ED}_{50} 0.4\right.$ and $0.8 \mathrm{mg} / \mathrm{kg}$, respectively). On the other hand, with the same oral dose of ecadotril and retorphan inhibition of the in vivo binding of $\left[{ }^{3} \mathrm{H}\right]$-racecadotril in mouse kidney was somewhat stronger for the $S$-isomer (Lecomte et al., 1990). Similarly, a 30-mg oral dose of ecadotril produced somewhat greater inhibition of NEP activity and ANP levels in human plasma than the same dose of retorphan (Lecomte et al., 1990).

In conclusion, racecadotril and its metabolite acetyl-thiorphan are only low potency NEP inhibitors. However, racecadotril is rapidly converted to the active metabolite thiorphan in vitro (Lecomte et al., 1986) and in vivo (see Pharmacokinetic and<smiles>CC(=O)SCC(Cc1ccccc1)C(=O)NCC(=O)O</smiles>

Acetylthiorphan<smiles>CC[C@H](Cc1ccccc1)C(=C[Si](C)(C)C(C)=O)C(=O)NCC(=O)OCc1ccccc1</smiles>

Racecadotril<smiles>O=C(O)CNC(=O)C(CS)Cc1ccccc1</smiles>

Thiorphan

FIGURE 1 | Chemical structures of racecadotril and its two metabolites thiorphan and acetyl-thiorphan. The blue arrows indicate the sites of metabolization; the asterisk indicates the chiral center of the molecule. 
Drug-Drug Interaction Studies), and thiorphan is an about 1000 times more potent NEP inhibitor than racecadotril with reported potencies of $0.4-9 \mathrm{nM}$. The $S$-isomers of racecadotril and thiorphan may be slightly more potent than the $R$-isomers.

\section{PHARMACOKINETIC AND DRUG-DRUG INTERACTION STUDIES}

\section{ANIMAL PHARMACOKINETIC STUDIES}

In mice, following i.v. administration, racecadotril was rapidly metabolized to thiorphan; thus, $30 \mathrm{~min}$ after the injection only thiorphan was recovered from the kidney whereas the parent compound racecadotril was not detected (de la Baume et al., 1988). In rats $92 \%$ of a single-dose $(10 \mathrm{mg} / \mathrm{kg})$ of radioactively labeled racecadotril was eliminated within $24 \mathrm{~h}$ (Matheson and Noble, 2000).

\section{HUMAN PHARMACOKINETIC STUDIES}

Racecadotril is rapidly absorbed following oral administration. For example, in a single-dose, placebo-controlled, double-blind cross-over study racecadotril doses of 30,100 , and $300 \mathrm{mg}$ reached $C_{\max }$ within $60 \mathrm{~min}$ after oral administration; the latter two doses were associated with significant inhibition of plasma NEP activity seen as early as $30 \mathrm{~min}$ after ingestion, and that inhibition exhibited a $t_{1 / 2}$ of $3 \mathrm{~h}$ (Lecomte, 2000; Matheson and Noble, 2000). A singledose study in healthy elderly people reported similar findings (Matheson and Noble, 2000). After ingestion of a single oral dose of $300 \mathrm{mg}$ racecadotril plasma thiorphan levels peaked after $60 \mathrm{~min}$ reaching 805-1055 nM; after $240 \mathrm{~min}$ plasma levels were still at 92-204 nM (Hinterleitner et al., 1997). In a more recent study, a well validated liquid chromatography/tandem mass spectrometry method has been used to detect thiorphan in human plasma; 20 volunteers received a single oral dose of $200 \mathrm{mg}$ racecadotril, which resulted in a thiorphan $C_{\max }$ of $520 \mathrm{ng} / \mathrm{mL}$, a $t_{\max }$ of $1.35 \mathrm{~h}$ and a $t_{1 / 2}$ of $6.14 \mathrm{~h}$ (Xu et al., 2007). The pharmacokinetic properties of racecadotril are similar with chronic dosing as observed in a placebo-controlled, double-blind study with 30,100, and $300 \mathrm{mg}$ racecadotril being given orally thrice daily for 7 days, where pharmacokinetic parameters were similar on day 1 and day 7 and to the values observed in the single-dose studies (Matheson and Noble, 2000), indicating lack of accumulation upon chronic dosing. Concomitant food intake does not modify the bioavailability of racecadotril but peak NEP inhibition is delayed by about $90 \mathrm{~min}$ (data on file).

After oral administration racecadotril is rapidly and effectively metabolized to the active metabolite thiorphan which is the predominant species detected in plasma; the occurrence of thiorphan coincides in time with the inhibition of plasma NEP (Hinterleitner et al., 1997; Xu et al., 2007). Thiorphan has a plasma protein binding of approximately $90 \%$ (data on file).

An important question for any drug interfering with the endogenous opioid system is whether it crosses the blood-brainbarrier, i.e., whether upon oral racecadotril administration parent compound or active metabolite reaches relevant levels in the brain to cause NEP inhibition. Animal studies suggest that central nervous effects can occur after parenteral administration of racecadotril but not after oral racecadotril or parenteral thiorphan administration (see Studies on Central Nervous System
Function); this is the apparent result of the combination of the rapid conversion of absorbed racecadotril to thiorphan and the lack of thiorphan passage through the blood-brain-barrier due to its less lipophilic chemical structure (Figure 1). In line with these animal data it has been reported that i.v. administration of racecadotril causes quantitatively similar NEP inhibition in plasma and cerebrospinal fluid in five healthy volunteers as compared to saline infusion (Spillantini et al., 1986), whereas a single high oral racecadotril dose $(20 \mathrm{mg} / \mathrm{kg})$ to two volunteers caused a marked reduction of plasma NEP activity within $30 \mathrm{~min}$ but did not affect liquor NEP activity (Lecomte, 2000). In accordance with the proposed lack of central nervous effects of orally administered racecadotril, a placebo-controlled cross-over study in 12 subjects being treated with $300 \mathrm{mg} / \mathrm{kg}$ racecadotril for 3 days did not detect any impairment of vigilance (Lecomte, 2000).

The active racecadotril metabolite thiorphan is converted to inactive metabolites, but the pathways mediating this conversion have not been characterized in great detail. While two studies using different methodological approaches have reported that racecadotril inhibits CYP 3A4-mediated formation of metabolites of the cancer chemotherapeutic drug irinotectan with an $\mathrm{IC}_{50}$ of $46 \mu \mathrm{M}$ in human liver microsomes (Haaz et al., 1998a,b), it should be noted that this concentration is equivalent to about 10,000 times the potency of thiorphan for NEP inhibition. Thus, in concentrations which are achieved by therapeutic doses racecadotril is neither an inhibitor nor an inducer of cytochrome P450 enzymes and also not a substrate of the P-glycoprotein transporter (data on file). Accordingly, to date no interactions with other medicinal products have been identified and specifically concomitant treatment with loperamide or nifuroxazide does not affect the pharmacokinetics of racecadotril (data on file). Moreover, racecadotril does not modify protein binding of active substances strongly bound to proteins such as tolbutamide, warfarin, niflumic acid, digoxin, or phenytoin (data on file). The elimination of the inactive thiorphan metabolites occurs mainly via the renal route (data on file).

\section{STUDIES ON CENTRAL NERVOUS SYSTEM FUNCTION}

As discussed in Section "Pharmacokinetic and Drug-Drug Interaction Studies," parenteral administration of racecadotril can have central nervous effects but these are not apparent with oral racecadotril or parenteral thiorphan treatment. Most effects of racecadotril and its metabolites on brain function apparently are mediated by inhibition of enkephalin degradation, as opiate receptor antagonism in many cases abolishes them (see below).

\section{ANALGESIA}

Based on the role of morphine and other opiates in pain control, it was an obvious choice to test racecadotril in various pain models. The results have been rather inconsistent across models but much more consistent within models indicating that NEP inhibition selectively targets certain pain pathways. Thus, racecadotril was analgesic in the hot-plate jump test in unspecified mice with i.c.v. administration (Roques et al., 1980) and with i.v. administration in Swiss albino (Lecomte et al., 1986; Costentin et al., 1998), NMRI (Lambert et al., 1993, 1995) and DBA/2J mice but not C57BL/6J mice (Michael-Titus et al., 1989). Interestingly, in the latter study racecadotril increased locomotion in both strains, indicating that 
the difference in analgesic effect does not reflect a pharmacokinetic strain difference. In NMRI mice i.v. acetyl-thiorphan and thiorphan were also effective in this model, although thiorphan less than the more lipophilic acetyl-thiorphan and racecadotril (Lambert et al., 1993, 1995). I.v. racecadotril was also analgesic in Swiss albino mice in the tail-withdrawal and the phenylbenzoquinoneinduced writhing test (Lecomte et al., 1986). In an arthritis-based pain model in rats (vocalization induced by applying pressure to the left hind paw) racecadotril also exhibited analgesic activity (Kayser and Guilbaud, 1983), but this was weaker than that of the mixed peptidase inhibitor kelatorphan in the same model (Kayser et al., 1989). In the same test racecadotril was not analgesic in nonarthritic rats (Kayser and Guilbaud, 1983). In unspecified mice i.c.v. thiorphan was ineffective in the tail removal test but enhanced the analgesic effects of several enkephalines which are NEP substrates but not of others which are not NEP substrates (Roques et al., 1980). Moreover, racecadotril did not exhibit analgesic properties in the hot-plate licking test in Swiss albino (Lecomte et al., 1986) or NMRI mice (Lambert et al., 1993) or in albino mice in the tail immersion test, but enhanced the anti-nociceptive effect of an exogenously administered enkephalin in the latter model (Livingston et al., 1988). In GB1 mice in the acetic acid-induced abdominal constriction assay racecadotril was effective only at subcutaneous doses of $10 \mathrm{mg} / \mathrm{kg}$ and higher (Gray et al., 1998).

Upon chronic stimulation the opioid system can exhibit both desensitization and sensitization. Thus, the analgesic response to i.v. racecadotril was blunted after 14 days of i.c.v. treatment with thiorphan in rats (Bousselmame et al., 1991a). However, no crossdesensitization between racecadotril and morphine was observed in mice (Bousselmame et al., 1991b) or rats, and in the latter also no cross-sensitization for locomotive effects was observed (Khallouk-Bousselmame and Costentin, 1994).

It has also been tested whether racecadotril can enhance analgesic effects of other treatments. Thus, racecadotril or thiorphan enhanced naloxone-sensitive analgesia induced by transcranial electrostimulation in rats (Malin et al., 1989) or by nefopam in mice (Gray et al., 1999), and also enhanced analgesic effects of electroacupunture in rats (Zhou et al., 1990). In the acetic acid-induced abdominal constriction pain model in GB1 mice racecadotril enhanced the analgesic effect of morphine and of anti-depressants such as dothiepine and amitriptyline (Gray et al., 1998). On the other hand, racecadotril did not enhance naloxonesensitive analgesic effects in four different pain models in mice (Michael-Titus and Costentin, 1987), and neither i.v. racecadotril nor i.c.v. thiorphan enhanced analgesic effects of dopamine receptor agonists in mice (Michael-Titus et al., 1990a). Another type of interaction between pain-related pathways was suggested by findings in mice in which nociceptin attenuated the analgesic response to racecadotril (Costentin et al., 1998).

In conclusion, racecadotril has direct analgesic effects and can enhance analgesic effects of some other types of drugs in some but not all pain models, but such studies were largely restricted to parenteral administration. Similar to direct opioid receptor agonists, racecadotril-induced analgesia can undergo desensitization upon long-term exposure but despite both morphine and racecadotril effects involving opioid receptors, they did not exhibit crossdesensitization. As the anti-nociceptive effects of racecadotril are restricted to some model systems, it can be expected that, if at all, racecadotril would be effective only in some forms of pain in patients and only upon parenteral administration; however, a clinical testing of potential analgesic effects of racecadotril in patients has not been reported to our knowledge.

\section{OTHER NERVOUS SYSTEM STUDIES}

The administration of natural or synthetic opioid receptor agonists elicits a locomotor response in rodents, which is considered to be an index of the activity of mesolimbic dopaminergic neurons. In both mice and rats i.v. racecadotril was reported to enhance locomotion in mice and rats in a naloxone-sensitive manner, and that response was blocked by a dopamine receptor antagonist and enhanced by a dopamine uptake inhibitor (Michael-Titus et al., 1987, 1990b). Similar to the analgesic racecadotril response (see Analgesia), the locomotor racecadotril response also was desensitized following a 14-day i.c.v. treatment with thiorphan (Bousselmame et al., 1991a). In line with the idea that racecadotril can affect dopaminergic transmission in the brain, it was found that i.v. racecadotril modulates dopaminergic transmission in rat olfactory tubercle but not striatum (Dourmap et al., 1990).

Both the opioid and the dopamine system in the brain are prone to addiction. Therefore, it was important to find that racecadotril did not exhibit abuse potential in rats or monkeys in doses up to $50 \mathrm{mg} / \mathrm{kg}$ (Knisely et al., 1989). Nevertheless, i.p. racecadotril prevented some but not all withdrawal symptoms in opioid-habituated mice and rats (Livingston et al., 1988; Dzolic et al., 1992). However, racecadotril alone was ineffective in inhibiting naloxone-induced morphine withdrawal symptoms in mice in another study, but a combination of subthreshold doses of racecadotril, CCK-4, and caerulein was effective (Bourin et al., 1999). In a double-blind, double-dummy, clinical proof-ofconcept study in 19 heroin-addicted patients comparing $50 \mathrm{mg}$ i.v. racecadotril and $75 \mu \mathrm{g}$ oral clonidine; racecadotril appeared more effective than clonidine against objective withdrawal symptoms as quantified by the Himmelsbach scale, whereas both treatments were similarly effective against subjective withdrawal symptoms (Hartmann et al., 1991).

Some studies have explored potential metabolic effects of racecadotril. In sheep oral and i.v. administration of racecadotril increased food intake, whereas i.c.v. thiorphan reduced it; as oral racecadotril treatment does not lead to NEP inhibition in the brain and as i.c.v. thiorphan did not mimick the racecadotril effects, this appears to be a peripheral effect (Riviere and Bueno, 1987). Moreover, naltrexone blocked the former but not the latter effect, indicating an involvement of peripheral opioid receptors. A study with i.v. racecadotril in cats reported increases in sham food intake (Bado et al., 1989). In rats i.v. racecadotril caused naloxoneinsensitive dose-dependent lowering of blood glucose which was accompanied by increased plasma insulin and C-peptide levels (Wu et al., 2010). While racecadotril did not affect insulin release from isolated pancreatic islets, the muscarinic receptor antagonist atropine blocked and the cholinesterase inhibitor physostigmine enhanced the racecadotril-induced insulin elevation, indicating that they may occur via modulation of parasympathetic nerve activity. In a follow-up study the same investigator group provided evidence that i.v. racecadotril and i.c.v. thiorphan directly inhibit 
an insulin-degrading enzyme in the brain, and that brain insulin acts via the vagal nerve on plasma glucose (Lee et al., 2011). The clinical findings of these intriguing observations have not been explored in patients to our knowledge.

In a mouse behavioral dispair test, a model system for antidepressant effects, immobility time was reduced by $10 \mathrm{mg} / \mathrm{kg}$ i.v. or $50 \mathrm{mg} / \mathrm{kg}$ i.p. in mice (Lecomte et al., 1986). Moreover, it was reported that thiorphan can provide neuroprotection in newborn mice (Medja et al., 2006).

\section{CARDIOVASCULAR STUDIES}

Most effects of racecadotril and its metabolites in the cardiovascular system apparently are largely mediated by inhibition of degradation of the natriuretic peptides. Thus, racecadotril-, ecadotril-, or thiorphan-induced inhibition of ANP break-down and/or elevation of ANP levels have been demonstrated in rats (Fink et al., 1996; Stasch et al., 1996), mice (Gros et al., 1989, 1990a,b; Lecomte et al., 1990; Stasch et al., 1996), and humans (Gros et al., 1989; Dussaule et al., 1991, 1993; Piquard et al., 2002) as assessed in plasma (Gros et al., 1989, 1990b; Lecomte et al., 1990; Dussaule et al., 1991, 1993; Schmitt et al., 1994; Fink et al., 1996; Stasch et al., 1996; Piquard et al., 2002) or in tissues such as kidney (Gros et al., 1989, 1990a). The increase in circulating ANP concentrations is typically associated with increased concentrations of the ANP-generated second messenger cyclic GMP in plasma (Dussaule et al., 1993; Stasch et al., 1995, 1996; Cleland and Swedberg, 1998; Piquard et al., 2002) or urine of animals and patients (Lecomte et al., 1990; Dussaule et al., 1991; Schmitt et al., 1994; Stasch et al., 1995, 1996; Cleland and Swedberg, 1998; Kimura et al., 1998; Duncan et al., 1999). The racecadotril and ecadotril effects on plasma ANP may be even more pronounced in patients (see below). Based on these findings, racecadotril has been studied in various animal models, in healthy volunteers, and in patient groups in which an increased exposure to ANP has been deemed beneficial.

An important physiological effect of ANP is promoting diuresis and natriuresis. Based on the consistent racecadotril effects on ANP, effects of racecadotril have been studied in various animal models and in humans. Thus, oral racecadotril treatment increased natriuresis in normotensive rats, which was accompanied by enhanced diuresis in some (Bralet et al., 1990) but not other studies (Stasch et al., 1995, 1996). Racecadotril-induced diuresis and natriuresis have also been reported in healthy volunteers (Gros et al., 1989; Lecomte et al., 1990). This was accompanied by an elevated glomerular filtration rate and lowered renal blood flow whereas plasma aldosterone concentration, renin activity, and mean arterial blood pressure were not altered (Schmitt et al., 1994).

\section{TREATMENT OF ARTERIAL HYPERTENSION}

Racecadotril has been tested in various animal models of hypertension, specifically for its ability to lower blood pressure, improve renal function, and to prevent or reverse organ hypertrophy. These models include spontaneously hypertensive rats (Bralet et al., 1990) and its stroke-prone substrain (Stasch et al., 1995), transgenic rats harboring a mouse renin gene (Stasch et al., 1996), hypertension induced by treatment with the immunosuppressant cyclosporine $\mathrm{A}$ in rats (Takeda et al.,
2000), and the rat deoxycorticosterone acetate-salt model of mineralocorticoid-induced hypertension (Ito et al., 1999). Blood pressure lowering by oral racecadotril or ecadotril was consistently shown (Stasch et al., 1995, 1996; Ito et al., 1999; Takeda et al., 2000). In a first pilot study in 12 hypertensive patients receiving increasing sinorphan doses $(25-200 \mathrm{mg}$ bid) for a total of 6 weeks a dose-dependent blood pressure reduction was also observed (Lefrancois et al., 1990). In a subsequent randomized, double-blind clinical pilot study with a cross-over design in 16 hypertensive patients racecadotril was less effective than captopril in lowering blood pressure, but the combination of both drugs was more effective than either monotherapy (Favrat et al., 1995).

In line with the effects in normotensive animals and healthy human volunteers, racecadotril also increased diuresis and/or natriuresis in spontaneously hypertensive rats (Bralet et al., 1990), in transgenic rats (Stasch et al., 1996) and in deoxycorticosterone acetate-salt-treated rats (Ito et al., 1999) whereas numerical increases of diuresis and natriuresis did not yield statistical significance in stroke-prone spontaneously hypertensive rats (Stasch et al., 1995).

A prognostically relevant complication of hypertension is the development of hypertrophy of the heart and other cardiovascular organs. In this regard, chronic treatment with racecadotril reduced heart hypertrophy in stroke-prone spontaneously hypertensive rats (Stasch et al., 1995), in transgenic rats (Stasch et al., 1996) and in deoxycorticosterone acetate-salt-treated rats (Ito et al., 1999). A reduction of renal enlargements was observed less consistently in these studies.

Taken together these studies demonstrate beneficial effects of treatment with racecadotril on blood pressure, renal function, and cardiac hypertrophy in various animal models of hypertension, which is in line with the elevated ANP levels in such animals. While clinical pilot studies have confirmed blood pressure lowering effects in hypertensive patients, these were too modest in comparison to established anti-hypertensive treatments to warrant further clinical investigation of racecadotril in this indication; potential enhancement of blood pressure lowering by other drugs was also deemed insufficient to be of clinical relevance.

\section{TREATMENT OF CONGESTIVE HEART FAILURE}

Congestive heart failure leads to atrial dilatation which is the most important physiological stimulus for ANP secretion. This enhanced ANP secretion is generally seen as a counter-measure to increase diuresis and natriuresis and thereby lower cardiac after-load. Accordingly, racecadotril has been evaluated in animal models and in patients with heart failure. Animal models of heart failure in which racecadotril or ecadotril have been tested include rats with volume overload due to aortic valve insufficiency (Kimura et al., 1998) or to an atrio-ventricular fistula (Wegner et al., 1996), rats after a myocardial infarction (Duncan et al., 1999), dogs with coronary microembolization (Olivier et al., 2000; Mishima et al., 2002), and dogs with heart failure due to sino-atrial pacing (Solter et al., 2000).

In line with the fluid retention, an activation of the reninangiotensin system is a hallmark of congestive heart failure. Such activation was mitigated by treatment with racecadotril in animal models (Wegner et al., 1996; Kimura et al., 1998; Duncan et al., 
1999). A similarly reduced activity of the renin-angiotensin system was observed in an early and short-term pilot study in heart failure patients (Kahn et al., 1990) but not in a larger chronic study in such patients (Cleland and Swedberg, 1998). Whether indirectly by reducing activity of the renin-angiotensin system or more directly by increasing ANP exposure, diuretic and/or natriuretic effects of racecadotril were observed in the volume overload rats (Wegner et al., 1996), coronary microembolization dogs (Olivier et al., 2000), and in dogs with pacing-induced heart failure (Solter et al., 2000) but not in post-myocardial infarction rats (Duncan et al., 1999). Accordingly, improvements of the cardiac pump function were observed in most of these models (Kimura et al., 1998; Olivier et al., 2000; Mishima et al., 2002), whereas blood pressure did not change (Mishima et al., 2002).

Some of these heart failure models, particularly those involving volume or pressure overload typically lead to cardiac hypertrophy. In line with the other findings it has been found that chronic racecadotril treatment ameliorates such cardiac hypertrophy in the volume overload rat models (Wegner et al., 1996; Kimura et al., 1998). Similarly, racecadotril treatment also reduced cardiac hypertrophy in the dog microembolization model (Mishima et al., 2002). However, in the post-myocardial infarction rat model neither racecadotril nor perindopril alone reduced development of cardiac hypertrophy whereas their combination did (Duncan et al., 1999).

In accordance with the observed increase in plasma ANF and/or urinary cGMP, three studies have explored whether racecadotril or ecadotril may have therapeutic benefit in heart failure patients. In a series of small pilot studies in patients with severe heart failure (left ventricular ejection fraction 20\%), 2 days of ecadotril treatment doubled plasma ANP levels despite starting from a markedly elevated baseline (Kahn et al., 1990). This was accompanied by a reduced renin activity and pulmonary capillary wedge pressure. Based on those encouraging findings a clinical, placebocontrolled dose-ranging study (50-400 mg ecadotril twice daily for 6 months) was performed in 259 patients with moderate heart failure (left ventricular ejection fraction of $<35 \%$; Cleland and Swedberg, 1998). This confirmed a dose-dependent increase in plasma and urinary cGMP but patients did not show reduced activation of the renin-angiotensin system or, more importantly, clinical improvement. Another study in a similar population of 50 moderate heart failure patients with 10 weeks of treatment with increasing racecadotril doses (up-titration from 50 to $400 \mathrm{mg}$ twice daily) also failed to demonstrate clinical improvement (O'Connor et al., 1999).

Taken together racecadotril has shown promising findings in animal models of congestive heart failure but patient studies have not confirmed a sufficient clinical potential to warrant further development in this indication.

\section{TREATMENT OF OTHER CARDIOVASCULAR CONDITIONS}

Racecadotril has also been tested in animal models and/or clinical pilot studies for various other indications related to cardiovascular function. Studies in rats have reported that i.v. racecadotril may protect the heart against adrenaline-induced arrhythmia (Lishmanov et al., 2001) or against arrhythmia induced by short ischemia-reperfusion episodes (Naryzhnaia et al., 2001), the latter effect being blocked by a $\delta$-opioid receptor antagonist. In a mouse model of pulmonary hypertension ecadotril was found to have synergistic beneficial effects with sildenafil (Baliga et al., 2008).

In a single-dose pilot study in liver cirrhosis patients racecadotril 30 and $100 \mathrm{mg}$ increased plasma ANP and cGMP and caused a transient diuresis and natriuresis response relative to placebo; the activity of the renin-angiotensin system apparently was not affected in these patients (Dussaule et al., 1991). In a single-dose cross-over pilot study in chronic renal failure patients $100 \mathrm{mg}$ ecadotril inhibited enkephalinase, increased plasma cGMP and natriuresis; aldosterone, glomerular filtration rate, or blood pressure were not affected (Dussaule et al., 1993). Finally, a single dose of $200 \mathrm{mg}$ ecadotril increased plasma endothelin-1, ANP, and cGMP and diuresis and natriuresis in a randomized placebocontrolled study in heart transplant recipients (Piquard et al., 2002).

\section{STUDIES IN THE GASTRO-INTESTINAL TRACT}

Most effects of racecadotril and its metabolites on gastro-intestinal function apparently are mediated by inhibition of enkephalin degradation, as opiate receptor antagonism in many cases abolishes them (see below). However, an inhibition of the degradation of neuropeptide $\mathrm{Y}$ and the closely related peptide YY by NEP may also be involved as both of these peptides have anti-secretory effects in the gut (Playford and Cox, 1996).

\section{EXPERIMENTAL STUDIES RELATED TO DIARRHEA}

It is well established that enkephalines have potent anti-secretory properties in the gut but do not affect gut motility (Turvill and Farthing, 1997). In an initial study in rats, i.v. racecadotril inhibited castor oil-induced diarrhea, an effect which was abolished by the opioid receptor antagonist naloxone (Lecomte et al., 1986). Such findings in the castor oil model of diarrhea were confirmed in rats with oral racecadotril and with i.v. thiorphan; they were blocked by subcutaneous but not by i.c.v. naloxone, indicating that the opioid receptors mediating this effects are located peripherally (Marcais-Collado et al., 1987). Racecadotril also reduced castor oil-induced diarrhea in human volunteers in a placebo-controlled study (Baumer et al., 1992).

To explore the underlying mechanism of anti-diarrhea effects of racecadotril, several studies have been performed. Thus, excessive fluid secretion from the gut is a pathophysiological hallmark of diarrhea. Racecadotril inhibited cholera toxin-induced but not basal secretion in canine jejunum (Primi et al., 1999). This was confirmed in a parallel group study in human volunteers, in which cholera toxin was administered by segmental perfusion directly into the proximal jejunum (Hinterleitner et al., 1997). In another study, racecadotril inhibited secretion induced by rotavirus infection in an in vitro model of intestinal secretion, Caco-2 cells (Guarino et al., 2009), a model which may be of value because rotavirus infection is a very frequent cause of childhood diarrhea.

A potential complication of diarrhea treatment is inhibition of intestinal motility as it can lead to secondary constipation and, perhaps even more important, intestinal retention of harmful infectious organisms. In rats oral $40 \mathrm{mg} / \mathrm{kg}$ racecadotril was reported not to affect gastro-intestinal transit time, whereas $2 \mathrm{mg} / \mathrm{kg}$ loperamide did (Marcais-Collado et al., 1987). Using the 
same approach in mice, $20 \mathrm{mg} / \mathrm{kg}$ i.v. of racecadotril or thiorphan or $0.5 \mathrm{mg} / \mathrm{kg}$ oral loperamide also did not significantly affect transit time, whereas $10 \mathrm{mg} / \mathrm{kg}$ oral or $0.5 \mathrm{mg} / \mathrm{kg}$ i.v. loperamide significantly prolonged it (Marcais-Collado et al., 1987). A potential consequence of effects on gastro-intestinal transit time was explored in newborn piglets, in which a 4-day oral treatment with $20 \mathrm{mg} / \mathrm{kg}$ racecadotril twice daily did not significantly affect E. coli content of the proximal jejunum, whereas $1 \mathrm{mg} / \mathrm{kg}$ oral loperamide twice daily markedly increased it; accordingly, the E. coli content of the stool was significantly reduced by loperamide but not by racecadotril (Duval-Ilfah et al., 1999). In placebo-controlled studies in human volunteers racecadotril treatment for up to 1 week also did not modify oro-coecal, colonic or overall gastro-intestinal transit times (Baumer et al., 1989; Bergmann et al., 1992).

In conclusion, both racecadotril and direct $\mu$-opioid receptor agonists have effects on the gut which lead to limitation of pathological fluid loss. While the receptor agonists do so primarily by prolonging transit time and hence providing more opportunity for fluid reabsorption, racecadotril does so by inhibiting fluid secretion; the latter may be preferable as it directly targets the primary pathophysiological mechanism underlying acute diarrhea and also reduces the chance of retention of infectious agents in the gut.

\section{NON-DIARRHEA GASTRO-INTESTINAL STUDIES}

I.v. administration of racecadotril was shown to inhibit gastric secretion in cats induced by pentagastrin, histamine or 2-deoxyD-glucose in a naloxone-sensitive manner, whereas the mealinduced secretion was not affected (Bado et al., 1987). In rats i.v. racecadotril and i.c.v. thiorphan, but not i.v. thiorphan, inhibited gastric acid secretion; this was no longer observed following vagotomy, indicating a central nervous system-mediated effect (Chicau-Chovet et al., 1988). In mice i.p. racecadotril and thiorphan given prior to a fatty meal enhanced gastric emptying in a naloxone-sensitive manner; gastric emptying in response to a non-fat meal was enhanced by low and inhibited by a high thiorphan dose in a naloxone-resistant manner, and racecadotril was without significant effect under these conditions (Liberge et al., 1988).

Effects of racecadotril have also been investigated in the feline gall bladder. In a feline cholecystitis model racecadotril inhibited fluid secretion in a naloxone-sensitive manner, but did not block fluid transport in the normal gall bladder (Jivegard et al., 1989). In that study racecadotril also caused transient gall bladder contraction and increased bile outflow from the liver. In another study in the same species i.v. racecadotril but not i.v. thiorphan caused naloxone-sensitive contraction of the spincter Oddi, indicating a central nervous system-mediated effect (Thune et al., 1992).

In a controlled cross-over study in 10 healthy volunteers, $2.5 \mathrm{mg} / \mathrm{kg}$ i.v. racecadotril attenuated relaxation of the lower esophagus sphincter but did not affect contraction (Chaussade et al., 1988). Racecadotril enhanced the propagation of electrical signals in the distal colon in rats in the fasted and fed state in a naloxone-sensitive manner (Benouali et al., 1993). In a study in healthy volunteers racecadotril produced an atropine-resistant promotion of electrical activity in the rectum, which was absent in patients with Hirschsprung's disease (Grimaud et al., 1989).

\section{PLACEBO-CONTROLLED STUDIES IN ADULTS WITH ACUTE DIARRHEA}

The data of all controlled studies with racecadotril in the treatment of acute diarrhea in adults are summarized for efficacy in Table 1 and for adverse events in Figure 2. The original registration of racecadotril as a treatment for acute diarrhea in adults in France in 1992 was based on three placebo-controlled studies. In a double-blind, placebo-controlled, randomized dose-ranging study 49-55 patients per group with acute diarrhea presumed to be due to food poisening or infection-related received 30,100, or $300 \mathrm{mg}$ racecadotril or placebo three times per day until recovery for up to 10 days (data on file). The primary outcome parameter was time to cure, which was $68.4,69.6,65.0$, and $72.0 \mathrm{~h}$ with 30,100 , and $300 \mathrm{mg}$ racecadotril and placebo, respectively (not significant). Secondary outcome parameters included number of diarrhoic stools in the first $10 \mathrm{~h}(2.0-2.2$ with the three racecadotril doses as compared to 2.7 days with placebo; $p=0.06$ ) and in first 3 days (6.8-7.7 with the three racecatodril doses as compared to 8.6 days with placebo; $p=0.03)$. The incidence of the adverse events anal burning, painful anal contractions, spontaneous abdominal pain, nausea, vomiting, loss of appetite, asthenia, and insomnia did not differ significantly between groups.

In a double-blind, randomized, placebo-controlled study adult out-patients with acute diarrhea of presumed infectious origin having started less than 5 days before (95 on racecadotril, 98 on placebo) were treated with an initial dose of $200 \mathrm{mg}$ racecadotril followed by an additional $100 \mathrm{mg}$ dose after each unformed bowel movement until recovery or for a maximum of 10 days (Baumer et al., 1992). Resolution of diarrhea occurred significantly faster in a Kaplan-Meier type analysis with racecadotril than with placebo, e.g., on day 4 the cumulative probability of recovery was $75 \%$ with racecadotril vs. $37 \%$ with placebo. Accordingly, mean duration of treatment was $3.0 \pm 0.2$ days with active treatment vs. $4.4 \pm 0.3$ days with placebo. Several secondary endpoints including anal burning, spontaneous abdominal pain, nausea, anorexia, pain on abdominal palpation, and abdominal distension were also significantly improved by racecadotril as compared to placebo. The percentage of patients reporting adverse effects with racecadotril and placebo was 16.8 vs. $18.4 \%$, respectively.

In another double-blind, parallel group, placebo-controlled study 70 adult patients with acute diarrhea of presumed infectious origin were included and randomized to receive $100 \mathrm{mg}$ racecadotril or placebo three times daily until recovery for a maximum of 6 days (Hamza et al., 1999). The primary outcome parameter was mean stool weight, which was significantly smaller in the racecadotril as compared to the placebo group (355 \pm 35 vs. $499 \pm 46$ g, respectively). Secondary outcome parameters for which racecadotril was significantly superior to placebo included number of diarrhoic stools after 1 day of treatment $4.3 \pm 0.4$ vs. $5.4 \pm 0.4$, respectively) and percentage of patients passing at least one formed stool on the second day of treatment (15.6 vs. $5.3 \%$, respectively). The incidence of reported adverse events was $3.1 \%$ with racecadotril vs. $5.3 \%$ with placebo; abdominal distension, not classified as an adverse event in this study, was 5.6\% with racecadotril vs. $18.2 \%$ with placebo.

Following registration in 1992, one additional double-blind, randomized, placebo-controlled trial was performed in 110 men with cholera, in which $100 \mathrm{mg}$ racecadotril was administered every 
Table 1 | Efficacy of racecadotril in the treatment of acute diarrhea in adults.

\begin{tabular}{|c|c|c|c|c|}
\hline Outcome parameter & Number of patients & Racecadotril & Comparator & Reference \\
\hline \multicolumn{5}{|c|}{ DOUBLE-BLIND, PLACEBO-CONTROLLED STUDIES IN ADULTS WITH ACUTE DIARRHEA } \\
\hline Time to recovery, h & $54-55$ per group vs. $49^{\S}$ & $65.0-69.9$ & 72.0 & data on file \\
\hline Stool weight, g & 32 vs. 38 & $355 \pm 35^{*}$ & $499 \pm 46$ & Hamza et al. (1999) \\
\hline \multicolumn{5}{|c|}{ DOUBLE-BLIND, PLACEBO-CONTROLLED STUDIES IN ADULTS WITH CHOLERA } \\
\hline Number of stools per day & 15 (sequential racecadotril vs. no treatment) & $4.9^{*}$ & 6.3 & Dorval et al. (1995) \\
\hline \multicolumn{5}{|c|}{ STUDIES IN ADULTS WITH DELAYED DIARRHEA DUE CANCER CHEMOTHERAPY (IRINOTECAN) } \\
\hline Treatment responder & 11 & $36 \%$ & - & Saliba et al. (1998) \\
\hline Prophylaxis of diarrhea & 68 vs. 68 no treatment & $55 \%$ & $59 \%$ & Ychou et al. (2000) \\
\hline \multicolumn{5}{|c|}{ OCTREOTIDE-CONTROLLED STUDIES IN ADULTS WITHTREATMENT-RESISTANT DIARRHEA IN AIDS PATIENTS } \\
\hline \multicolumn{5}{|c|}{ DOUBLE-BLIND, LOPERAMIDE-CONTROLLED STUDIES IN ADULTS WITH ACUTE DIARRHEA } \\
\hline Duration of diarrhea, $\mathrm{h}$ & 473 vs. 472 & 55.0 & 55.0 & Prado (2002) \\
\hline Duration of diarrhea, $\mathrm{h}$ & 31 vs. 31 & 19.5 & 13.0 & Wang et al. (2005) \\
\hline Time recovery, h & 30 vs. 31 & $36 \pm 4^{*}$ & $63 \pm 6$ & Gallelli et al. (2010) \\
\hline
\end{tabular}

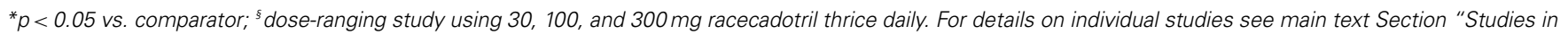
the Gastro-Intestinal Tract."

$4 \mathrm{~h}$ until recovery for a maximum of $72 \mathrm{~h}$ as an adjunct to standard treatment (Alam et al., 2003). Both treatments did not differ significantly with regard to total stool output, duration of diarrhea or patients with resolution of diarrhea within $72 \mathrm{~h}$. Adverse events noted as per-protocol such as vomiting, reappearance of dehydration, abdominal pain, headache, or anorexia were not different between the treatment groups. Taken together these studies consistently demonstrate efficacy of racecadotril as compared to placebo with similar adverse event incidences with both treatments. However, it should be noted that treatment regimens and outcome parameter varied considerably between studies.

\section{STUDIES IN OTHER FORMS OF ADULT DIARRHEA}

Some studies have been performed with racecadotril in the context of diarrhea associated with cancer chemotherapy. In a pilot study in 15 cancer patients treated with 5-fluoro-uracil were given a daily dose of $300 \mathrm{mg} / \mathrm{d}$ racecadotril for 7 days for the treatment of acute diarrhea (Dorval et al., 1995). As compared to the control period, i.e., earlier cycle of chemotherapy, the number of stools per day was reduced in each patient with a statistically significant reduction of mean number from 6.3 to 4.9 and the number of days with liquid stools significantly dropped from 4.7 to 2.4 .

Delayed onset diarrhea is a dose-limiting side-effect of the second-line anti-cancer drug irinotecan, which is often used in the treatment of colon cancer. Among patients exhibiting delayed diarrhea upon irinotecan treatment, 4 out of 11 patients responded to $100 \mathrm{mg}$ racecadotril thrice daily in one cohort, whereas 9 of 10 patients responded to a combination of racecadotril and loperamide ( $p<0.02$ vs. racecadotril alone) (Saliba et al., 1998). In a randomized open-label study 136 patients receiving a total of 714 irinotecan chemotherapy cycles received $300 \mathrm{mg} / \mathrm{d}$ racecadotril for
15 days as a prophylactic treatment or no prophylactic treatment but the two groups did not differ significantly in the incidence or severity of delayed diarrhea (Ychou et al., 2000).

In an open, randomized cross-over study the efficacy of $100-300 \mathrm{mg}$ racecadotril thrice daily and $50-150 \mu \mathrm{g}$ octreotide thrice daily was compared in 13 treatment-resistant diarrhea in AIDS patients (Beaugerie et al., 1996). From a baseline of $7.0 \pm 1.2 \mathrm{stools} /$ day racecadotril caused a significant reduction to $4.6 \pm 1.1$ stools/day, whereas octreotide caused a non-significant reduction to only $5.6 \pm 1.2$ stools/day. Daily lipid output was increased non-significantly by racecadotril, but was nearly doubled with octreotide.

\section{RACECADOTRIL CLINICAL STUDIES VS. PLACEBO AND OPEN STUDIES IN CHILDREN}

Based upon the results of racecadotril in the treatment of acute diarrhea in adults, several studies have explored its use in the treatment of acute diarrhea in children. The data of all controlled studies with racecadotril in the treatment of acute diarrhea in children are summarized for efficacy in Table 2 and for adverse events in Figure 3. In the first of such studies 135 boys aged 3-35 months including 73 with a verified rotavirus infection with $1.5 \mathrm{mg} / \mathrm{kg}$ racecadotril every $8 \mathrm{~h}$ or placebo in a randomized, double-blind study with both treatments being administered on top of oral rehydration solution (Salazar-Lindo et al., 2000). Total stool output in the first $48 \mathrm{~h}$ of treatment, the primary study endpoint, was $157 \pm 27 \mathrm{~g} / \mathrm{kg}$ with racecadotril as compared to $331 \pm 39 \mathrm{~g} / \mathrm{kg}$ with placebo $(p<0.001)$. The duration of diarrhea was significantly shorter with racecadotril ( $28 \mathrm{~h}$ regardless of rotavirus status) than with placebo treatment $(72$ and $52 \mathrm{~h}$ in rotavirus-positive and negative boys, respectively). Moreover, the amount of required oral 


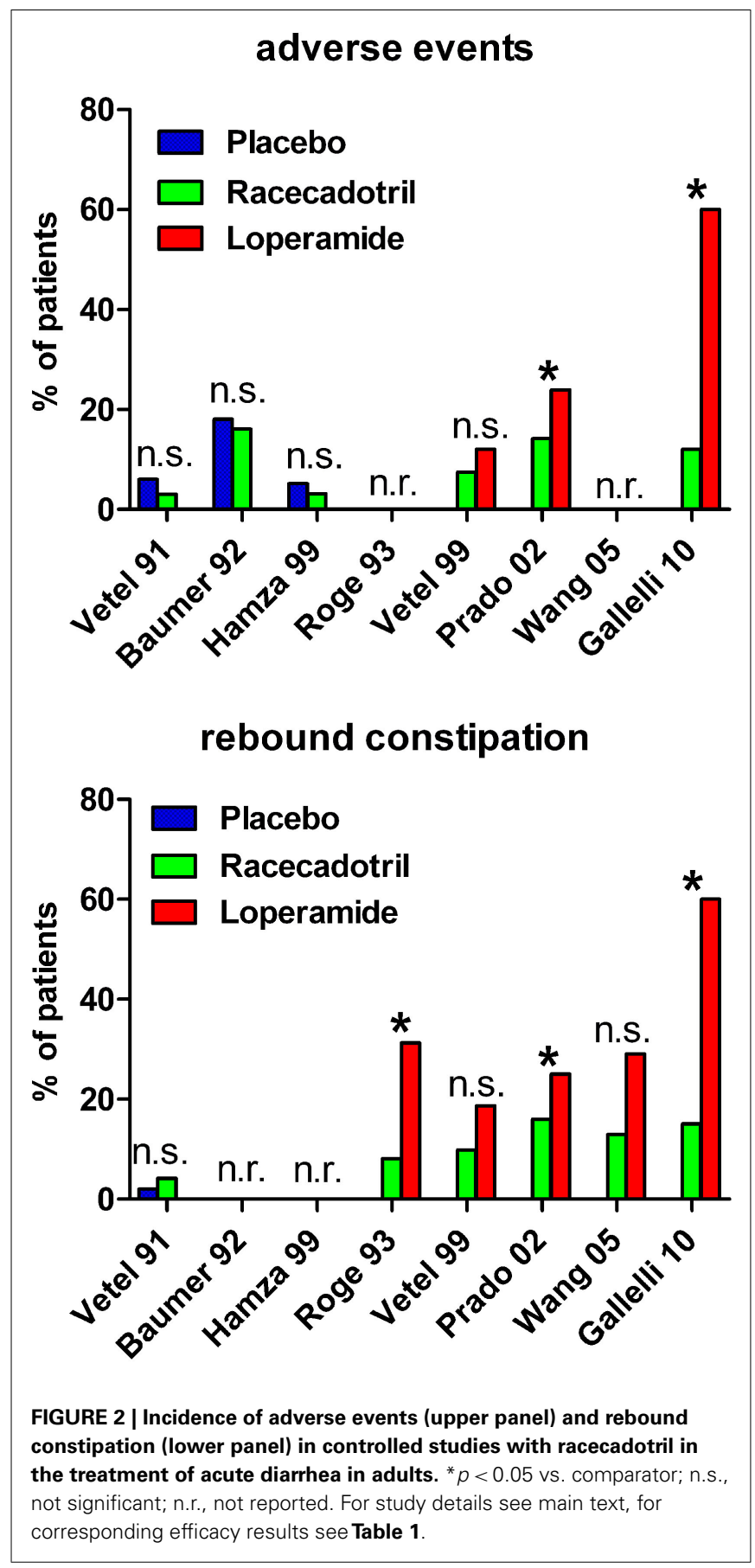

rehydration solution was also significantly less with racecadotril treatment. Adverse events were reported in 7 of 68 and 5 of 67 children receiving racecadotril and placebo, respectively; 51 and $52 \%$ reported vomiting at at least some point during treatment, and study withdrawal occurred in 9 and 14 patients, respectively.

A second double-blind, placebo-controlled randomized study of very similar design with racecadotril on top of oral rehydration solution was performed in 173 infants aged 3 months to 4 years, except that this study included children of both genders (Cezard et al., 2001). Total stool output was significantly lower

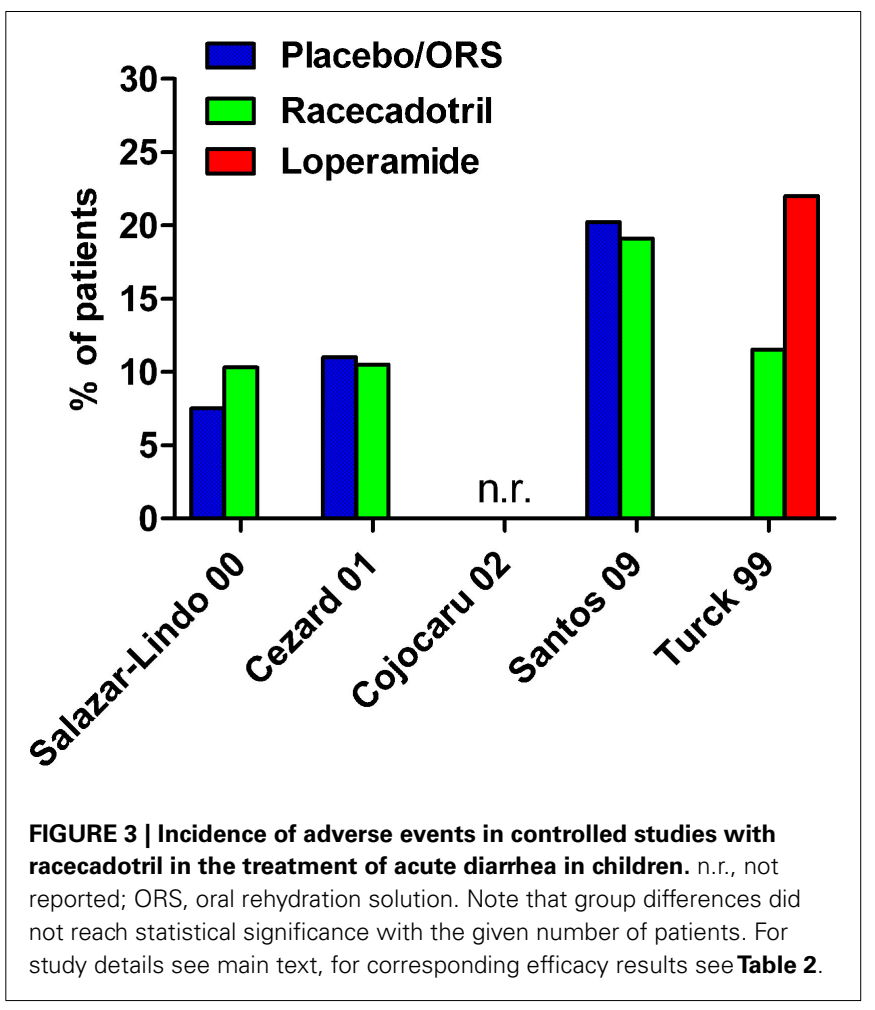

by $60 \%$ (95\% confidence interval $43-88 \%)$ with racecadotril as compared to placebo, and this was again independent of rotavirus status. Stool output in the first $24 \mathrm{~h}$ of treatment, a secondary endpoint, was also significantly less with racecadotril. The time to recovery was also significantly shorter with racecadotril in a Kaplan-Meier analysis. Moreover, the need for oral rehydration solution on the second day of treatment was also significantly lower with racecadotril treatment. Adverse events were reported by nine patients of each group, but abdominal distension was not noted in either treatment group.

In a third study the effect of racecadotril given as adjunct to oral rehydration solution was compared to rehydration alone in 166 children aged 3-34 months in a randomized open-label study (Cojocaru et al., 2002). The primary endpoint was the number of medical exams within a week after start of treatment which was significantly lower with racecadotril than without (14 vs. 27). Secondary endpoints the number of stools within the first $48 \mathrm{~h}(6.8 \pm 3.8$ vs. $9.5 \pm 4.5)$ and the duration of diarrhea $(97.2 \pm 35.6$ vs. $137.7 \pm 42.4 \mathrm{~h})$ were also significantly less in the racecadotril group.

In an open-label parallel group study 189 children aged 3-36 months were treated with oral rehydration solution or racecadotril ( 10 or $30 \mathrm{mg}$ thrice daily for children with $9-13$ or $>13 \mathrm{~kg}$ body weight, respectively) on top of such solution until two normal stools were observed or no bowel movement occurred within $12 \mathrm{~h}$ for up to 7 days (Santos et al., 2009). The primary endpoint, number of bowel movements in the first $48 \mathrm{~h}$ after initiation of treatment, did not differ significantly between the two treatments $(4.1 \pm 2.7$ vs. $3.8 \pm 2.4$ for control and racecadotril, respectively), and the duration of gastroenteritis, a secondary 
Table 2 | Efficacy of racecadotril in the treatment of acute diarrhea in children.

\begin{tabular}{|c|c|c|c|c|}
\hline Outcome parameter & Number of patients & Racecadotril & Comparator & Reference \\
\hline \multicolumn{5}{|c|}{ DOUBLE-BLIND, PLACEBO-CONTROLLED STUDIES IN CHILDREN WITH ACUTE DIARRHEA } \\
\hline Stool output, g/kg & 68 vs. 65 & $157 \pm 27^{*}$ & $331 \pm 39$ & Salazar-Lindo et al. (2000) \\
\hline \multicolumn{5}{|c|}{ OPEN-LABEL CONTROLLED STUDIES (VS. REHYDRATION ALONE) IN CHILDREN WITH ACUTE DIARRHEA } \\
\hline Medical exams within 1 week of treatment & 81 vs. 83 & $14^{*}$ & 27 & Cojocaru et al. (2002) \\
\hline Time to relief, $\mathrm{h}$ & 3873 & $18.5 \pm 12.5$ & n.a. & Chacon (2010) \\
\hline \multicolumn{5}{|c|}{ DOUBLE-BLIND, LOPERAMIDE-CONTROLLED STUDIES IN CHILDREN WITH ACUTE DIARRHEA } \\
\hline Number of diarrhoic stools until recovery & 52 vs. 50 & $2.7 \pm 0.4$ & $2.1 \pm 0.4$ & Turck et al. (1999) \\
\hline
\end{tabular}

n.a., Not applicable; ${ }^{*} p<0.05$ vs. comparator.

endpoint, also differed numerically but not significantly $(4.7 \pm 2.2$ vs. $4.0 \pm 2.1$ days, respectively). The incidence of adverse events was similar in both treatment groups (20.2 vs. $19.1 \%$, respectively).

In an open-label study 3873 children aged 3 months to 12 years were treated with $1.5 \mathrm{mg} / \mathrm{kg}$ thrice daily (Chacon, 2010). The primary endpoint of that study was time to relief, time from start of treatment to last watery bowel movement, which was reached after $18.5 \pm 12.5 \mathrm{~h}$ (95\% confidence interval 17.9-19.0 h). Using the very large number of children in this study, the authors have performed a multiple regression analysis to explore factors affecting drug performance. Among a range of potential explanatory variables diarrhea severity was the only with a significant and independent weight on racecadotril effectiveness, explaining 23\% of time to relief variance, but even in severe cases mean time to relief was less than $24 \mathrm{~h}$. Specific adverse event incidence was not reported, but overall tolerability was rated as excellent or good in 95.9\% of cases.

While some of the above mentioned randomized pediatric studies have been systematically reviewed in the past (Szajewska et al., 2007; Tormo et al., 2008), those analyses covered only part of the existing trial databases. More importantly, an individual patient meta-analysis of nine pediatric studies with raw data available for analysis from 1384 children has been reported more recently which also included some studies that had not been reported before as full papers (Lehert et al., 2011). The proportion of children with recovery was higher with racecadotril treatment with a hazard ratio of 2.04 (95\% confidence interval 1.85-2.32). For in-patient studies, the ratio of mean stool output racecadotril/placebo was $0.59(0.51-0.74, p<0.001)$, for out-patient studies, the ratio of the mean number of diarrhoic stools racecadotril/placebo was $0.63(0.51-0.74, p<0.001)$.

Accordingly, a survey of treatment patterns among all officebased pediatricians in France found racecadotril to be prescribed by $62 \%$ of pediatricians as compared to only $28 \%$ prescribing loperamide (Uhlen et al., 2004). In line with the above studies, as an addition to oral rehydration treatment, racecadotril is being recommended for the treatment of acute diarrhea in children by recent guidelines, e.g., from the World Gastroenterology Organisation (World Gastroenterology Association, 2008), the European Society of Pediatric Gastroenterology, Hepatology and Nutrition/European Society for Pediatric Infectious Diseases (Guarino et al., 2008), a guideline panel from Spain and Latin America (Gutierrez Castrelion et al., 2010), and the German Society for Pediatric Gastroenterology and Nutrition (Koletzko and Lentze, 2008). Similarly, a very recent international panel of experts from France, Ireland, Italy, Malaysia, Peru, Spain, USA, and Vietnam emphasized that oral rehydration solution is the basis of the treatment of acute diarrhea in children; the use of loperamide was discouraged, whereas racecadotril was recognized as an option for additional active treatment on top of rehydration solution (Guarino et al., 2012).

\section{RACECADOTRIL CLINICAL STUDIES VS. LOPERAMIDE (ADULTS AND CHILDREN)}

As loperamide has been the primary medical treatment of acute diarrhea for a long time, particularly in adults, six studies have reported direct comparisons of the efficacy and tolerability of racecadotril and loperamide including one study in children.

Roge et al. (1993) reported a double-blind controlled study in which $100 \mathrm{mg}$ racecadotril was compared to $1.33 \mathrm{mg}$ loperamide (two doses at start of treatment, followed by one dose every $8 \mathrm{~h}$ ) in 37 vs. 32 patients, respectively. The study did not report a primary endpoint but rather several outcome parameters in parallel including physician evaluation of efficacy, time to diarrhea resolution, abdominal pain for more than 1 day, abdominal distension for more than 1 day, duration of abdominal distension and secondary constipation. Racecadotril was numerically superior to loperamide for all of these endpoints, and the difference reached statistical significance for the latter three. The authors did not specifically report incidence of adverse events but secondary constipation can be considered as such and was found significantly less frequent in racecadotril as compared to loperamide-treated patients ( 8.1 vs. $31.3 \%)$.

A second randomized, double-blind, double-placebo-controlled study compared the efficacy and safety of $100 \mathrm{mg}$ racecadotril thrice daily with that of $2 \mathrm{mg}$ loperamide after each diarrhoic stool in 82 and 75 patients, respectively, administered until recovery for a maximum of 7 days (Vetel et al., 1999). Both groups passed a similar number of stools $(3.5 \pm 0.5$ vs. $2.9 \pm 0.4)$ and had a similar duration of diarrhea $(14.9 \pm 2.0$ vs. $13.7 \pm 2.2 \mathrm{~h})$. Adverse events 
were reported in $7.4 \%$ of racecadotril and $12 \%$ of loperamide patients, and rebound constipation was experienced by $9.8 \%$ of racecadotril vs. $18.7 \%$ of loperamide patients.

The third and largest direct head-to-head study compared 473 patients receiving $100 \mathrm{mg}$ racecadotril thrice daily with 472 patient receiving $2 \mathrm{mg}$ loperamide thrice daily in a single-blind design (Prado, 2002). The primary efficacy criterion was duration of diarrhea, defined as time between start of treatment and appearance of first formed stool; this was $55.0 \mathrm{~h}$ in both groups (95\% confidence interval $50.0-65.0$ and $48.0-66.0 \mathrm{~h}$ in the racecadotril and loperamide group, respectively). The median duration of abdominal pain was similar in both groups, but difference in pain intensity between start and end of study was significantly in favor of racecadotril; moreover, a significantly greater percentage of patients reported residual pain at study end with loperamide as compared to racecadotril treatment (7 vs. 3\%). Rebound constipation (objectively defined as $36 \mathrm{~h}$ without passing stool) was significantly more frequent with loperamide than with racecadotril treatment (25 vs. 16\%). The incidence of reported adverse events was also significantly greater with loperamide than with racecadotril (23.9 vs. $14.2 \%$ ).

A fourth randomized study compared 31 patients receiving $100 \mathrm{mg}$ racecadotril thrice daily to 31 patients receiving $2 \mathrm{mg}$ loperamide twice daily in a single-blind manner (Wang et al., 2005). The primary endpoint was duration of diarrhea, which did not differ significantly between treatments (median 19.5 vs. $13.0 \mathrm{~h}$ for racecadotril and loperamide, respectively). Duration of abdominal pain, abdominal distension, anal burning, and nausea also did not differ significantly between treatments. Adverse events were reported in $25.0 \%$ of racecadotril and $22.0 \%$ of loperamide patients. Among these rebound constipation was reported in four and nine racecadotril and loperamide patients, respectively, whereas itching was found in two racecadotril but no loperamide patients.

A fifth double-blind, randomized study compared $100 \mathrm{mg}$ racecadotril thrice daily to loperamide (4 mg starting dose, followed by $2 \mathrm{mg}$ after each unformed stool for a maximum of $8 \mathrm{mg} / \mathrm{d}$ ) in 30 and 31 patients, respectively, being administered until recovery which was defined by two consecutive normal stools or no stools in a 12-h period (Gallelli et al., 2010). In contrast to the other studies, this one recruited only elderly nursing home residents with acute diarrhea (mean age 82 years). The primary endpoint was time to recovery which was met significantly earlier with racecadotril than with loperamide treatment ( $36 \pm 4$ vs. $63 \pm 6 \mathrm{~h}$ ). Secondary endpoints included duration of abdominal pain, number of diarrhea episodes, and total stool output in the intention-to-treat and in the per-protocol populations; racecadotril was numerically superior to loperamide all of these, and this reached statistical significance in several cases. In $50 \%$ of patients loperamide was ineffective within 4 days; these were switched to racecadotril resulting in rapid normalization of all symptoms. Adverse events were reported in $12 \%$ of racecadotril and $60 \%$ of loperamide patients; the latter percentage is much higher than in other loperamide studies, probably due to the elderly population being studied. Specifically, nausea and rebound constipation were noted more frequently with loperamide than with racecadotril, whereas abdominal pain, headache, and anorexia were seen similarly with both treatments. Based on genotyping for cytochrome P450 3A4 and 2C8 it was excluded that the group differences were not attributable to the presence of ultra-rapid or poor metabolizers. In a pharmacoeconomic analysis the average cost in the loperamide group was twice as high as in the racecadotril group ( $€ 91.99$ vs. $€ 44.85$ ).

A sixth randomized study directly comparing racecadotril and loperamide in the treatment of acute diarrhea was performed in a pediatric population with a mean age of 4.7 years (range 210 years) in a double-blind, double-placebo design (Turck et al., 1999). Fifty-two children received $1.5 \mathrm{mg} / \mathrm{kg}$ racecadotril thrice daily and 50 received $0.03 \mathrm{mg} / \mathrm{kg}$ loperamide thrice daily. The primary endpoint was number of passed stools until recovery which did not differ significantly between the two groups $(2.7 \pm 0.4$ with racecadotril and $2.1 \pm 0.4$ with loperamide). The mean duration of diarrhea also did not differ significantly between groups $(10.7 \pm 1.7 \mathrm{~h}$ with racecadotril and $8.8 \pm 2.3 \mathrm{~h}$ with loperamide). Adverse events were noted in $11.5 \%$ of racecadotril and $22 \%$ of loperamide patients. There were only statistically significant differences between the two treatments: rebound constipation $(36.5 \%$ of racecadotril and $58 \%$ of loperamide patients) and need for concomitant medication (anti-emetics 5 vs. 8 , analgesics 0 vs. 3 patients, oral rehydration 0 vs. 2 , and laxatives 0 vs. 1 patient on racecadotril and loperamide, respectively.

Taken together these six studies demonstrate that the efficacy of racecadotril and loperamide in the treatment of acute diarrhea did not differ significantly for some endpoints in some studies, but that racecadotril was significantly more effective for at least some endpoints in some studies. The incidence of adverse events also was similar in some studies but significantly less frequent with racecadotril in some other studies. A much lower frequency of rebound constipation was seen with racecadotril in almost all studies. Thus, in comparison to loperamide racecadotril appeared to be superior in efficacy and tolerability when all studies are taken into consideration.

While the mechanisms underlying differential effects of racecadotril and loperamide in acute diarrhea have not been fully established, two candidates have emerged: Firstly, loperamide preferentially acts on $\mu$-opioid receptors (Dehaven-Hudkins et al., 1999), whereas endogenous enkephalines active both $\mu$ - and $\delta$ receptors (Huighebaert et al., 2003). Secondly, NEP inhibition will not only increase exposure to endogenous enkephalines but also to endogenous neuropeptide Y and, possibly, peptide YY, both of which have strong anti-secretory effects in the gut (Playford and Cox, 1996).

\section{SAFETY AND TOLERABILITY}

As summarized in Figure 2 for adult and Figure 3 for pediatric patients with acute diarrhea, the incidence of adverse events reported during treatment with racecadotril was consistently similar to that with placebo and similar to or significantly less frequent than that with loperamide. Of note secondary constipation was consistently less frequent with racecadotril than with loperamide; for details see specific study descriptions in section 6 . Therefore, the following will summarize published findings on non-clinical toxicity studies and will highlight clinical findings with potential relevance for safety and tolerability. 
With regard to general toxicity, no relevant findings were reported for single doses up to $2000 \mathrm{mg} / \mathrm{kg}$ and for chronic doses up to $100 \mathrm{mg} / \mathrm{kg}$ in dogs (Maertins et al., 2000). In mice no overt toxicity was observed upon i.p. treatment with $50 \mathrm{mg} / \mathrm{kg}$ racecadotril for 10 days (Lecomte et al., 1986). In a study with newborn gnotobiotic piglets an oral dose of $130 \mathrm{mg} / \mathrm{kg}$ racecadotril produced no signs of neurotoxicity and no deaths, whereas an equivalent high dose of $5 \mathrm{mg} / \mathrm{kg}$ loperamide resulted in death in three out of four piglets (Duval-Ilfah et al., 1999). In monkeys 12 months of treatment with up to 100 times the therapeutic human dose did not produce any toxic effects (Lecomte, 2000). Single doses of up to $2000 \mathrm{mg}$ have been administered in healthy volunteers without ill effects (Lecomte, 2000).

Several studies have specifically explored potential adverse events related to airway function, breathing and allergy. As substance $\mathrm{P}$ also is a NEP substrate, the effect of racecadotril on responses to exogenous substance $\mathrm{P}$ has been explored. In guinea pigs racecadotril enhanced pulmonary substance $P$ response (Lötvall et al., 1990). In humans $200 \mathrm{mg}$ racecadotril enhanced the flare response to substance $\mathrm{P}$ in asthmatic subjects (Nichol et al., 1992), and a dose of $300 \mathrm{mg}$ racecadotril enhanced the substance P-induced decrease in nasal conductance in healthy subjects and those with allergic rhinitis (Lurie et al., 1994). There is one case report of a 3 -year-old boy weighing $20 \mathrm{~kg}$ and reporting generalized edema with itching and aphonia after 2 days of treatment with $30 \mathrm{mg}$ racecadotril; upon additional testing this was classified as a non-allergic hypersensitivity response (Nucera et al., 2006). While respiratory depression is a typical effects of direct opioid receptor agonists with penetration to the central nervous system such as morphine, no respiratory depression was noted with acute i.v. or i.p. racecadotril doses of up to $100 \mathrm{mg} / \mathrm{kg}$ in mice (Lecomte et al., 1986).

Finally, there were a few isolated findings from animal studies. In rats racecadotril and thiorphan were reported to enhance the duration but not the frequency of uterine contractions in periparturient animals (Adjroud, 1995). Also in rats the angiotensin converting enzyme inhibitor captopril produced plasma extravasation; while racecadotril alone did not mimick this, it enhanced the captopril response (Sulpizio et al., 2004). However, both of these studies are difficult to place into context as no corresponding adverse events have been reported in patients. Thus, the overall non-clinical and clinical studies demonstrate that

\section{REFERENCES}

Adjroud, O. (1995). Peripheral excitatory effects of two enkephalinase inhibitors, acetorphan and thiorphan, and an enkephalin analogue, [D-Ala2-Met5]-enkephalinamide, on uterine motility in periparturient rats in vivo and in vitro. J. Reprod. Fertil. 104, 181-186.

Alam, N. H., Ashraf, H., Khan, W. A., Karim, M. M., and Fuchs, G. J. (2003). Efficacy and tolerability of racecadotril in the treatment of cholera in adults: a double-blind, randomised, controlled clinical trial. Gut 52, 1419-1423.

Bado, A., Chicau-Chovet, M., Appia, F., Dubrasquet, M., Lecomte, J. M., and Roze, C. (1987). Acetorphan, an enkephalinase inhibitor, decreases gastric secretion in cats. Peptides 8 , 89-93. Dubrasquet, M. (1989). Endogenous opioid peptides in the control of food intake in cats. Peptides 10, 967-971.

Baldi, F., Bianco, M. A., Nardone, G., Pilotto, A., and Zamparo, E.
Bado, A., Roze, C., Lewin, M. J. M., and

racecadotril is a safe drug with an overall tolerability profile similar to placebo.

\section{CONCLUSION}

Racecadotril is a low potency inhibitor of NEP, but upon oral administration it is rapidly and effectively metabolized to the potent NEP inhibitor thiorphan, with the latter not exhibiting penetration into the central nervous system. NEP inhibition affects the abundance of several endogenous peptides with enkephalins and ANP apparently being most important. Elevated exposure to ANP appears to underly most cardiovascular effects of racecadotril; while these tend to be beneficial they appear quantitatively insufficient to warrant therapeutic use in comparison to other available drug classes. Elevation of enkephalin exposure appears to underly most central nervous effects, most notably analgesia, but the pain relieving effects are inconsistent across animal models. Increased exposure to peripheral endogenous enkephalins appears to underly the gastro-intestinal racecadotril effects. Most prominent among them is an antisecretory effect in the gut which, in contrast to direct $\mu$-opioid receptor agonists, occurs in the absence of effects on gastro-intestinal transit time. The clinical correlate of these findings is therapeutic efficacy against acute diarrhea in adults and children with a tolerability profile similar to that of placebo. In multiple direct comparative studies in different patients populations (children, adults, elderly), countries (Western Europea, Latin Amercia, Asia), and settings (out-patients, inpatients, nursing home residents) racecadotril was at least as effective as loperamide, and in several of those studies exhibited significantly better tolerability than loperamide. Most notably, rebound constipation was consistently less frequent with racecadotril than with loperamide; while this is primarily a tolerability benefit, it may also be relevant with regard to the efficacy of clearance of infectious organisms as demonstrated in one study. Of note, study designs and particularly treatment endpoints differed considerably between studies. This can be seen as a weakness because it makes inter-study comparisons more difficult; however, it can also be seen as a benefit because consistent therapeutic effects across so many different settings witness rather robust efficacy and tolerability. While additional studies appear warranted several guidelines, specifically in pediatric indications, now recommend including racecadotril in the management of acute diarrhea. Whether other forms of diarrhea, e.g., in the context of cancer chemotherapy, also benefit from racecadotril treatment is not fully clear.

(2009). Focus on acute diarrhoeal disease. World J. Gastroenterol. 15, 3341-3348.

Baliga, R. S., Zhao, L., Madhani, M. Lopez-Torondel, B., Visintin, C., Selwood, D., Wilkins, M. R., MacAllister, R. J., and Hobbs, A. J. (2008). Synergy between natriuretic peptides and phosphodiesterase 5 inhibitors ameliorates pulmonary arterial hypertension. Am. J. Respir. Crit. Care Med. 178, 861-869.

Baumer, P., Akoue, K., Bergmann, J. F., Chaussade, S., Nepveux, P., Alexandre, C. L., Schwartz, J. C., and Lecomte, J. M. (1989). Acetorphan, a potent enkephalinase inhibitor, does not modify orocecal and colonic transit times in healthy subjects. Gastroenterol. Clin. Biol. 13, 947-948.

Baumer, P., Danquechin Dorval, E., Bertrand, J., Vetel, J. M., Schwartz, J. C., and Lecomte, J. M. (1992). Effects of acetorphan, an enkephalinase inhibitor, on experimental and acute diarrhoea. Gut 33, 753-758.

Beaugerie, L., Baumer, P., Chaussade, S., Berard, H., Pialoux, G., Le Quintrec, Y., Schwartz, J. C., and Lecomte, J. M. 
(1996). Treatment of refractory diarrhoea in AIDS with acetorphan and octreotide: a randomized crossover study. Eur. J. Gastroenterol. Hepatol. $8,485-489$.

Benouali, S., Berard, H., and Roche, M. (1993). Action of enkephalinase (EC 3.4.24.11) inhibition on the pre- and post-prandial electromyographic patterns of colon in rats. Neuropeptides 24, 299-305.

Bergmann, J. F., Chaussade, S., Couturier, D., Baumer, P., Schwartz, J. C., and Lecomte, J. M. (1992). Effects of acetorphan, an antidiarrhoeal enkephalinase inhibitor, on oro-caecal and colonic transit times in healthy volunteers. Aliment. Pharmacol. Ther. 6, 305-313.

Bourgoin, S., Le Bars, D., Artaud, F., Clot, A.-M., Bouboutou, R., Fournier-Zaluski, M.-C., Roques, B. P., Hamon, M., and Cesselin, F. (1986). Effects of kelatorphan and other peptidase inhibitors on the in vitro and in vivo release of methionine-enkephalin-like material from the rat spinal cord. J. Pharmacol. Exp. Ther. 238, 360-366.

Bourin, M., Malinge, M., Colmbel, M. C., and Vasar, E. (1999). Cholecystokinin receptor agonists block the jumping behaviour precipitated in morphine-dependent mice by naloxone. Eur. Neuropsychopharmacol. 9, 37-43.

Bousselmame, R., Eustache, M., Michael-Titus, A., and Costentin, J. (1991a). Chronic inhibition of enkephalinase induces changes in the antinociceptive and locomotor effects of the enekephalinase inhibitor acetorphan in rats. Neuropharmacology 30, 865-870.

Bousselmame, R., Michael-Titus, A., and Costentin, J. (1991b). Desensitization of $\mu$-opioid receptors does not modify the analgesia induced by an enkephalinase inhibitor. Eur. J. Pharmacol. 203, 295-297.

Bralet, J., Mossiat, C., Lecomte, J.M., Charpentier, S., Gros, C., and Schwartz, J.-C. (1990). Diuretic and natriuretic responses in rats treated with enkephalinase inhibitors. Eur. J. Pharmacol. 179, 57-64.

Cezard, J. P., Duhamel, J. F., Meyer, M., Pharaon, I., Bellaiche, M., Maurage, C., Ginies, J. L., Vaillant, J. M., Girardet, J. P., Lamireau, T., Poujol, A., Morali, A., Sarles, J., Olives, J. P., Whately-Smith, C., Audrain, S., and Lecomte, J. M. (2001). Efficacy and tolerability of racecadotril in acute diarrhea in children. Gastroenterology 120, 799-805.

Chacon, J. (2010). Analysis of factors influencing the overall effect of racecadotril on childhood diarrhea. Results from a real-world and postauthorization surveillance study in Venezuela. Ther. Clin. Risk Manag. 6, 293-299.

Chaussade, S., Hamm, R., Lecomte, J. M., Couturier, D., and Guerre, J. (1988). Effects of an enkephalinase inhibitor on esophageal motility in man. Gastroenterol. Clin. Biol. 12, 793-796.

Chicau-Chovet, M., Dubrasquet, M., Chariot, J., Tsocas, A., Lecomte, J.M., and Roze, C. (1988). Thiorphan and acetorphan inhibit gastric secretion by a cetntral, non-opioid mechanism in the rat. Eur. J. Pharmacol. 154, 247-254.

Cleland, J. G., and Swedberg, K. (1998). Lack of efficacy of neutral endopeptiadse inhibitor ecadotril in heart failure. The international ecadotril multi-centre dose-ranging study investigators. Lancet 351, 1657-1658.

Cojocaru, B., Bocquet, N., Timsit, S., Wille, C., Boursiquot, C., Marcombes, F., Garel, D., Sannier, N., and Cheron, G. (2002). Effect of racecadotril in the management of acute diarrhea in infants and children. Arch. Pediatr. 9, 774-779.

Costentin, J., Suaudeau, C., Florin, S., Meunier, J.-C., and Costen. (1998). Nociceptin-induced apparent hyperalgesia in mice as a result of the prevention of opioid autoanalgesic mechanisms triggered by the stress of an intracerebroventricular injection. Fundam. Clin. Pharmacol. $12,420-425$.

de la Baume, S., Brion, F., Dam Trung Truong, M., and Schwartz, J. C. (1988). Evaluation of enkephalinase inhibition in the living mouse, using $[3 \mathrm{H}]$ acetorphan as a probe. J. Pharmacol. Exp. Ther. 247, 653-660.

Dehaven-Hudkins, D. L., Cortex Burgos, L., Cassel, J. A., Daubert, J. D., Dehaven, R. N., Mansson, E., Nagasaka, H., Yu, G., and Yaksh, T. (1999). Loperamide (ADL 2-1294), an opioid antihyperalgesic agent with peripheral selectivity. J. Pharmacol. Exp. Ther. 289, 494-502.

Dorval, E. D., Regimbeau, C., Gamelin, E., Picon, L., and Berard, $\mathrm{H}$. (1995). Treatment of acute chemically induced diarrhea by inhibition of enkephalinase. Results of a pilot study. Gastroenterol. Clin. Biol. 19, 27-30.

Dourmap, N., Michael-Titus, A., and Costentin, J. (1990). Acetorphan, an enkephalinase inhibitor, modulates dopaminergic transmission in rat olfactory tubercle, but not in the nucleus accumbens and striatum. Eur. J. Neurosci. 2, 783-787.

Duncan, A. M., James, G. M., Anastasopoulos, F., Kladis, A., Briscoe, T. A., and Campbell, D. J. (1999). Interaction between neutral endopeptidase and angiotensin converting enzyme inhibition in rats with myocardial infarction: effects on cardiac hypertrophy and angiotensin and bradykinin peptide levels. J. Pharmacol. Exp. Ther. 289, 295-303.

Dussaule, J. C., Grange, J. D., Wolf, J. P., Lecomte, J. M., Gros, C. Schwartz, J. C., Bodin, F., and Ardaillou, R. (1991). Effect of sinorphan, an enkephalinase inhibitor, on plasma atrial natriuretic factor and sodium urinary excretion in cirrhotic patients with ascites. J. Clin Endocrinol. Metab. 72, 653-659.

Dussaule, J.-C., Michel, C., Peraldi, M. N., Lecomte, J. M., Gros, C., Mignon, F., and Ardaillou, R. (1993). Inhibition of neutral endopeptidease stimulates renal sodium excretion and patients with chronic renal failure. Clin. Sci. 84, 31-39.

Duval-Ilfah, Y., Barard, H., Baumer, P., Guillaume, P., Raibaud, P., Joulin, Y., and Lecomte, M. J. (1999). Effects of racecadotril and loperamide on bacterial proliferation and on the central nervous system of the newborn gnotobiotic piglet. Aliment. Phar macol. Ther. 13(Suppl. 6), 9-14.

Dzolic, M. R., Bokszanska, A., Korenhof, A. M., Kaplan, C. D., Dzolic, M., Rupreht, J., Zijlstra, F. J., Brinkman, E. C., and Cappendijk, S. L. (1992). The effects of orally active enkephalinase inhibitors on morphine withdrawal syndrome. Neuroreport 3, 637-640.

Farthing, M. J. (2000). Diarrhoea: a significant worldwide problem. Int. J. Antimicrob. Agents 14, 65-69.

Farthing, M. J. (2006). Antisecretory drugs for diarrheal disease. Dig. Dis. 24, 47-58.

Favrat, B., Burnier, M., Nussberger, J., Lecomte, J. M., Brouard, R., Waeber, B., and Brunner, H. R. (1995). Neutral endopeptidase versus angiotensin converting enzyme inhibition in essential hypertension. J. Hypertens. 13, 797-804.

Fink, C. A., Carlson, J. E., McTaggart, P. A., Qiao, Y., Webb, R., Chatelain, R., Jeng, A. Y., and Trapani, A. J. (1996). Mercaptoacyl dipeptidases as orally active dual inhibitors or angiotensin-converting enzyme and neutral endopeptidase. J. Med. Chem. 29, 3158-3168.

Fink, C. A., Qiao, Y., Berry, C. J., Sakane, Y., Ghai, R. D., and Trapani, A. J. (1995). New $\alpha$-thiol dipeptide dual inhibitors of angiotensin-I converting enzyme and neutral endopeptidase EC 3.4.24.11. J. Med. Chem. 38, 5023-5030.

Fournet-Bourguignon, M. P., Illiano, S., Lenaers, A., and Teisseire, B. (1992). Decrease in enkephalinase A number in kidney membranes from hypercholesterolemic and hypertensive rats. J. Recept. Res. 12, 401-412.

Gallelli, L., Colosimo, M., tolotta, G. A., Falcone, D., Luberto, L. Curto, L. S., Rende, P., Mazzei, F., Marigliano, N. M., De Sarro, G., and Cucchiara, S. (2010). Prospective randomized double-blind trial of racecadotril compared with loperamide in elderly people with gastroenteritis living in nursing homes. Eur. J. Clin. Pharmacol. 66, 137-144.

Giros, B., Gros, C., Schwartz, J. C., Danvy, D., Plaquevent, J. C., Duhamel, P., Vlaiculescu, A., Costentin, J., and Lecomte, J. M. (1987). Enantiomers of thiorphan and acetorphan: correlation between enkephalinase inhibition, protection of endogenous enkephalins and behavioral effects. J. Pharmacol. Exp. Ther. 243, 666-673.

Giros, B., Llorens-Cortes, C., Gros, C. and Schwartz, J.-C. (1986). The endogenous tripeptide Tyr-Gly-Gly as a possible metabolite of opioid peptides in rat brain: identification, regional distribution, effects of lesions and formation in depolarized slices. Peptides 7, 669-677.

Gray, A. M., Nevinson, M. J., and Sewell, R. D. (1999). The involvement of opioidergic and noradrenergic mechanisms in nefopam antinociception. Eur. J. Pharmacol. 365, 149-157.

Gray, A. M., Spencer, P. S., and Sewell, R. D. (1998). The involvement of the opiodergic system in the antinociceptive mechanism of action of antidepressant compounds. Br. J. Pharmacol. 124, 669-674.

Grimaud, J. C., Bouvier, M., Naudy, B., and Salducci, J. (1989). Noncholinergic neural excitation of the human rectum induced by acetorphan, an inhibitor of enkephalinase. Gastroenterol. Clin. Biol.13, 799-803.

Gros, C., Sougue, A., Schwartz, J. C., Duchier, J., Cournot, A., Baumer, P., and Lecomte, J. M. (1989). Protection of atrial natriuretic factor against degradation: diuretic and natriuretic responses after in vivo inhibition of enkephalinase (EC 3.4.24.11) by acetorphan. Proc. Natl. Acad. Sci. U.S.A. 86, 7580-7584.

Gros, C., Souque, A., and Schwartz, J. C. (1990a). Inactivation of atrial natriuretic factor in mice in vivo: crucial 
role of enkephalinase (EC 3.4.24.11). Eur. J. Pharmacol. 179, 45-56.

Gros, C., Souque, A., and Schwartz, J.-C. (1990b). Degradation of atrial natriuretic factor in mouse blood in vitro and in vivo: role of enkephalinase (EC 3.4.24.11). Neuropeptides 17, $1-5$.

Guarino, A., Albano, F., Ashkenazi, S., Gendrel, D., Hoekstra, J. H., Shamir, R., and Szajewska, H. (2008). European Society for Paedriatic Gastroenterology, Hepatology, and Nutrition/European Society for Paediatric Infections Diseases evidencebased guidelines for the management of acute gastroenteritis in children in Europe. J. Pediatr. Gastroenterol. Nutr. 46(Suppl. 2), S81-S184.

Guarino, A., Buccigrossi, V., and Armellino, C. (2009). Colon in acute intestinal infection. J. Pediatr. Gastroenterol. Nutr. 48(Suppl. 2), S58S62.

Guarino, A., Dupont, C., Gorelov, A. V., Gottrand, F., Lee, J. K., Lin, Z., Lo Vecchio, A., Nguyen, T. D., and Salazar-Lindo, E. (2012). The management of acute diarrhea in children in developed and developing areas: from evidence base to clinical practice. Expert Opin. Pharmacother. 13, 17-26.

Gutierrez Castrelion, P., Polanco Allue, I., and Salazar-Lindo, E. (2010). An evidence based Iberic-Latin American guideline for acute gastroenteritis management in infants and prescholars. Ann. Pediatr. 73, 220.e1-220.e20.

Haaz, M. C., Riche, C., Rivory, L. P., and Robert, J. (1998a). Biosynthesis of an aminopiperidino metabolite of irinotecan [7-ethyl-10[4-(1-piperidino)-1-piperidino] carbonyloxycampthothecine] by human hepatic mircosomes. Drug Metab. Dispos. 26, 769-774.

Haaz, M. C., Rivory, L., Riche, C., Vernillet, L., and Robert, J. (1998b). Metabolism of irinotecan (CPT-11) by human hepatic microsomes: participation of cytochrome P-450 3A and drug interactions. Cancer Res. 58, 468-472.

Hamza, H., Khalifa, H. B., Baumer, P., Berard, H., and Lecomte, J. M. (1999). Racecadotril versus placebo in the treatment of acute diarrhoea in adults. Aliment. Pharmacol. Ther. 13(Suppl. 6), 15-19.

Hartmann, F., Poirier, M. F., Bourdel, M. C., Loo, H., Lecomte, J. M., and Schwartz, J. C. (1991). Comparison of acetorphan with clonidine for opiate withdrawal symptoms. Am. J. Psychiatry 148, 627-629.
Hinterleitner, T. A., Petritsch, W., Dimsity, G., Berard, H., Lecomte, J. M., and Krejs, G. J. (1997). Acetorphan prevents cholera-toxininduced water and electrolyte secretion in the human jejunum. Eur. J. Gastroenterol. Hepatol. 9, 887-891.

Huighebaert, S., Awouters, F., and Tytgat, G. N. (2003). Racecadotril versus loperamide: antidiarrheal research revisited. Dig. Dis. Sci. 48 , 239-250.

Ito, H., Majima, M., Nakajima, S., Hayashi, I., Katori, M., and Izumi, T. (1999). Effect of prolonged administration of a urinary kinase inhibitor, ebelactone $\mathrm{B}$ on the development of deoxycorticosterone acetate-salt hypertension in rats. $\mathrm{Br}$. J. Pharmacol. 126, 613-620.

Jivegard, L., Pollard, H., Moreau, J., Schwartz, J. C., Thune, A., and Svanik, J. (1989). Naloxonereversible inhibition of gall-bladder mucosal fluid secretion in experimental cholecystitis in the cat by acetorphan, an enkephalinase inhibitor. Clin. Sci. 77, 49-54.

Kahn, J. C., Patey, M., Dubois-Rande, J. L., Merlet, P., Castaigne, A., Lim-Alexandre, C., Lecomte, J. M., Duboc, D., Gros, C., and Schwartz, J. C. (1990). Effect of sinorphan on plasma atrial natriuretic factor in congestive heart failure. Lancet 335, 118-119.

Kayser, V., Fournier-Zaluski, M. C., Guildbaud, G., and Roques, B. P. (1989). Potent antinociceptive effects of kelatorphan (a highly efficient inhibitor of multiple enkephalin-degrading enzymes) systemically administered in normal and arthritic rats. Brain Res. 497, 94-101.

Kayser, V., and Guilbaud, G. (1983). The analgesic effects of morphine, but not those of the enkephalinase inhibitor thiorphan, are enhanced in arthritic rats. Brain Res. 267, 131-138.

Khallouk-Bousselmame, R., and Costentin, J. (1994). Locomotor and analgesic effects of morphine and acetorphan in rats chronically treated with morphin or thiorphan. Eur. Neuropsychopharmacol. 4, 137-143.

Kimura, M., Umemura, K., Ohashi, K., and Nakashima, M. (1998). Effect of ecadotril, a neutral endopeptidase inhibitor, on myocardial hypertrophy in the rat aortic insufficiency model. Can. J. Cardiol. 14, 63-68.

Knisely, J. S., Beardsley, P. M., Aceto, M. D., Balster, R. L., and Harris, L. S. (1989). Assessment of the abuse potential of acetorphan, an enkephalinase inhibitor. Drug Alcohol Depend. 23, 143-151.

Koletzko, S., and Lentze, M. J. (2008). Leitlinien Pädiatrische Gastroenterologie: akute infektiöse Gastroenteritis. Available at: http://www.gpge.de/docs/ leitlinien_gastroenteritis.pdf

Lambert, D. M., Mergen, F., Berens, C. F., Poupaert, J. H., and Dumont, P. (1995). Synthesis and pharmacological properties of 2-[S-acetylthiorphan]-1,3diacylaminopropan-2-ol derivatives as chimeric lipid drug carriers containing an enkephalinase inhibitor. Pharm. Res. 12, 187-191.

Lambert, D. M., Mergen, F., Poupaert, J. H., and Dumont, P. (1993). Analgesic potency of S-acetylthiorphan after intravenous administration to mice. Eur. J. Pharmacol. 243, 129-134.

Lecomte, J. M. (2000). An overview of clinical studies with racecadotril in adults. Int. J. Antimicrob. Agents 14, 81-87.

Lecomte, J.-M., Baumer, P., Lim, C., Duchier, J., Cournot, A., Dussaule, J.C., Ardaillou, R., Gros, C., Chaignon, B., Souque, A., and Schwartz, J. C. (1990). Stereoselective protection of exogenous and endogenous atrial natriuretic factor by enkephalinase inhibitors in mice and humans. Eur. J. Pharmacol. 179, 65-73.

Lecomte, J.-M., Costentin, J., Vlaiculescu, A., Chaillet, P., MarcaisCollado, H., Llorens-Cortes, C., Leboyer, M., and Schwarz, J.-C. (1986). Pharmacological properties of acetorphan, a parenterally active "enkephalinase" inhibitor. $J$. Pharmacol. Exp. Ther. 237, 937-944.

Lee, J. P., Cheng, K. C., Chung, H. H., Chen, C. T., and Cheng, J. T. (2011). Inhibition of insulin degrading enzyme by racecadotril in the brain of Wistar rats. Horm. Metab. Res. 43, 489-493.

Lefrancois, P., Clerc, G., Duchier, J., Lim, C., Lecomte, J. M., Gros, C., and Schwartz, J. C. (1990). Antihypertensive activity of sinorphan. Lancet 336, 307-308

Lehert, P., Cheron, G., Calatayud, G. A., Cezard, J.-P., Castrellon, P. G., Melendez Garcia, J.-M., Santos, M., and Savitha, M. R. (2011). Racecadotril for childhood gastroenteritis: an individual patient data meta-analysis. Dig. Liver Dis. 43, 707-713.

Liberge, M., Riviere, P. M., and Bueno, L. (1988). Influence of enkephalinase inhibitors on gastric emptying in mice depends on the nature of the meal. Life Sci. 42, 2047-2053.
Lishmanov, I. U. B., Maslov, L. N., and Uskina, E. V. (2001). Antiarrhythmia effects of enkephalinase inhibitors. Eksp. Klin. Farmakol. 64, 28-30.

Livingston, S. J., Sewell, R. D., Rooney, K. F., and Smith, H. J. (1988). Amelioration of naloxone-precipitated opioid withdrawal symptoms by peripheral administration of the enkephalinase inhibitor acetorphan. Psychopharmacology (Berl.) 94, 540-544.

Llorens-Cortes, C., Gros, C., and Schwartz, J.-C. (1986). Steady-state level and turnover rate of the tripeptide Tyr-Gly-Gly as indexes of striatal enkephalin release in vivo and their reduction during pentobarbital anesthesia. Proc. Natl. Acad. Sci. U.S.A. 83, 6226-6230.

Llorens-Cortes, C., Gros, C., Schwartz, J. C., Clot, A. M., and Le Bars, D. (1989). Changes in levels of the tripeptide Tyr-Gly-Gly as an index of enkephalin release in the spinal cord: effects of noxious stimuli and parenterally-active peptidase inhibitors. Peptides 10, 609-614.

Lötvall, J. O., Skoogh, B.-E., Barnes, P. J., and Chung, K. F. (1990). Effects of aerosolised substance $\mathrm{P}$ on lung resistance in guinea-pigs: a comparison between inhibition of neutral endopeptidase and angiotensinconverting enzyme. Br. J. Pharmacol. 100, 69-72.

Lurie, A., Nadel, J.A., Roisman, G., Siney, H., and Dusser, D. J. (1994). Role of neutral endopeptidase and kininase II on substance P-induced increase in nasal obstruction in patients with allergic rhinitis. Am. J. Respir. Crit. Care Med. 149, 113-117.

Maertins, T., von Ketz, E., and Goetze, L. (2000). Acute, subchronic, and chronic toxicity of ecadotril in dogs. Am. J. Vet. Res. 61, 425-429.

Malin, D. H., Lake, J. R., Hamilton, R. F., and Skolnick, M. H. (1989). Augmented analgesic effects of enkephalinase inhibitors combined with transcranial electrostimulation. Life Sci. 44, 1371-1376.

Marcais-Collado, H., Uchida, G., Costentin, J., Schwartz, J. C., and Lecomte, J. M. (1987). Naloxonereversible antidearrheal effects of enkephalinase inhibitors. Eur. J. Pharmacol. 144, 125-132.

Matheson, A. J., and Noble, S. (2000). Racecadotril. Drugs 59, 829-835.

Medja, F., Lelievre, V., Lebas, F., Leroux, P., Quimet, T., Saria, A., Rougeot, C., Dournaud, P., and Gressens, P. (2006). Thiorphan, a neutral endopeptidase inhibitor used for diarrhoea, is neuroprotective 
in newborn mice. Brain 129, 3209-3223.

Michael-Titus, A., Bousselmame, R., and Costentin, J. (1990a). Stimulation of dopamine D2 receptors induces an analgesia involving an opioidergic but non enkephalinergic link. Eur. J. Pharmacol. 187, 201-207.

Michael-Titus, A., Dourmap, N., Costentin, J., and Schwartz, J. C. (1990b). Role of delta opioid receptors in the effects of inhibitors of enkephalindegrading peptidases on the horizontal and vertical components of locomotion in mice. Neuropeptides 15, 89-100.

Michael-Titus, A., and Costentin, J. (1987). Analgesic effects of metapramine and evidence against the involvement of endogenous enkephalins in the analgesia inducec by tricyclic antidepressants. Pain 31, 391-400.

Michael-Titus, A., Dourmap, N., Caline, H., Costentin, J., and Schwartz, J. C. (1989). Role of endogenous enkephalins in locomotion and nociception studied with peptidase inhibitors in two inbred strains of mice (C57BL/6J and DBA/2J). Neuropharmacology 28, 117-122.

Michael-Titus, A., Preterre, P., Giros, B., and Costentin, J. (1987). Role of endogenous enkephalins in locomotion evidenced by acetorphan, an "enkephalinase" inhbitor. J. Pharmacol. Exp. Ther. 243, 1062-1066.

Mishima, T., Tanimura, M., Suzuki, G., Todor, A., Sharov, V. G., Tanhehco, E. J., Goldstein, S., and Sabbah, H. N. (2002). Effects of chronic neutral endopeptidase inhibition on the progression of left ventricular dysfunction and remodeling in dogs with moderate heart failure. Cardiovasc. Drugs Ther. 16, 209-214.

Naryzhnaia, N. V., Krylatov, A. V., Maslov, L. N., Lishmanov, I. U. B., Gross, G. J., and Stephano, J. B. (2001). Role of delta opioid receptors and their ligands in the development of adaptive heart protection against arrhythmogenesis. Ross. Fiziol. Zh. Im. I. M. Sechenova 87, 1617-1625.

Nichol, G. M., O’Connor, B. J., Lecomte, J. M., Chung, K. F., and Barnes, P. J. (1992). Effect of neutral endopeptidase inhibitor on airway function and bronchial responsiveness in asthmatic subjects. Eur. J. Clin. Pharmacol. 42, 491-494.

Nucera, E., Schiavino, D., Altomonte, G., Buonomo, A., Sabato, V., and Patriarca, G. (2006). Hyperensitivity to racecadotril: a case report. Eur. J. Pediatr. 165, 418-419.
O'Connor, C. M., Gattis, W. A., Gheorghiade, M., Granger, C. B., Gilbert, J., McKenney, J. M., Messineo, F. C., Burnett, J. C., Katz, S. D., Elkayam, U., Kasper, E. K., Goldstein, S., Cody, R. J., and Massie, B. M. (1999). A randomized trial of ecadotril versus placebo in patients with mild to moderate heart failure: the U.S. Ecadotril pilot safety study. Am. Heart J. 138, 1140-1148.

Olivier, N. B., Kutas, S. M., Beals, S., Hanson, B., and Windram, S. (2000). Short-term effects of ecadotril in dogs with induced congestive heart failure. Am. J. Vet. Res. 61, 333-338.

Piquard, F., Richard, R., Charloux, A., Duotreleau, S., Hannedouche, T., Brandenberger, G., and Geny, B. (2002). Hormonal, renal, hemodynamic responses to acute neutral endopeptidase inhibition in heart transplant patients. J. Appl. Physiol. 93, 569-575.

Playford, R. J., and Cox, H. M. (1996). Peptide YY and neuropeptide Y: two peptides intimately involved in electrolyte homeostasis. Trends Pharmacol. Sci. 17, 436-438.

Prado, D. (2002). A multinational comparison of racecadotril and loperamide in the treatment of acute watery diarrhoea in adults. Scand. J. Gastroenterol. 37, 656-661.

Primi, M. P., Bueno, L., Baumer, P., Berard, H., and Lecomte, J. M. (1999). Racecadotril demonstrates intestinal antisecretory activity in vivo. Aliment. Pharmacol. Ther. 13(Suppl. 6), 3-7.

Riviere, P. J., and Bueno, L. (1987). Origin of the stimulation of food intake by oral administration of enkephalinase inhibitors in sheep. Life Sci. 41 , 333-339.

Roge, J., Baumer, P., Berard, H., Schwartz, J.-C., and Lecomte, J.-M. (1993). The enkephalinase inhibitor, acetorphan, in acute diarrhoea. A double-blind, controlled clinical trial versus loperamide. Scand. J. Gastroenterol. 28, 352-354.

Roques, B. P., Fournie-Zaluski, M.-C., Soroca, E., Lecomte, J. M., Malfroy, B., Llorens, C., and Schwartz, J. C. (1980). The enkephalinase inhibitor thiorphan shows antinociceptive activity in mice. Nature 288, 286-288.

Salazar-Lindo, E., Santisteban-Ponce, J., Chea-Woo, E., Gutierrez, M. (2000). Racecadotril in the treatment of acute watery diarrhea in children. $N$. Engl. J. Med. 343, 463-437.

Saliba, F., Hagipantelli, R., Misset, J. L., Bastian, G., Vassal, G., Bonnay, M., Herait, P., Cote, C., Mahjoubi, M., Mignard, D., and
Cvitkovic, E. (1998). Pathophysiology and therapy of irinotecaninduced delayed-onset diarrhea in patients with advanced colorectal cancer: a prospective assessment. $J$. Clin. Oncol. 16, 2745-2751.

Santos, M., Maranon, R., Miguez, C. Vazquez, P., and Sanchez, C. (2009). Use of racecodatril as outpatient treatment for acute gastroenteritis: a prospective, randomized, parallel study. J. Pediatr. 155, 62-67.

Schmitt, F., Martinez, F., Ikeni, A., Savoiu, C., Natov, S., Laborde, K., Lacour, B., Grünfeld, J. P., and Hannedouche, T. (1994). Acute renal effects of neutral endopeptidase inhibition in humans. Am. J. Physiol. 267, F20-F27.

Schwartz, J. C. (2000). Racecadotril: a new approach to the treatment of diarrhoea. Int. J. Antimicrob. Agents 14, 75-79.

Solter, P., Sisson, D., Thomas, W., and Goetze, L. (2000). Intrarenal effects of ecadotril during acute volume expansion in dogs with congestive heart failure. J. Pharmacol. Exp. Ther. 293, 989-995.

Spillantini, M. G., Geppetti, P., Fanciullacci, M., Michelacci, S., Lecomte, J. M., and Sicuteri, F. (1986). In vivo 'enkephalinase' inhibition by acetorphan in human plasma and CSF. Eur. J. Pharmacol. 125, 147-150.

Stasch, J. P., Hirth-Dietrich, C., Ganten, D., and Wegner, M. (1996). Renal and antihypertensive effects of neutral endopeptidase inhibition in transgenic rats with an extra renin gene. Am. J. Hypertens. 9, 795-802.

Stasch, J. P., Knorr, A., Wegner, M., and Hirth-Dietrich, C. (1995). Prolonged inhibition of neutral endopeptidase 24.11 by sinorphan in stroke-prone spontaneously hypertensive rats. Hypertens. Res. 18, 137-143.

Sulpizio, A. C., Pullen, M. A., Edwards, R. M., and Brooks, D. P. (2004). The effect of acute angiotensinconverting enzyme and neutral endopeptidase 24.11 inhibition on plasma extravasation in the rat. J. Pharmacol. Exp. Ther. 309, 1141-1147.

Szajewska, H., Ruszczynski, M., Chmielewska, A., and Wieczorek, J. (2007). Systematic review: racecadotril in the treatment of acute diarrhoea in children. Aliment. Pharmacol. Ther. 26, 807-813.

Takeda, Y., Inaba, S., Furukawa, K., Fujimura, A., Miyamori, I., and Mabuchi, H. (2000). Effects of chronic neutral endopeptidase inhibition in rats with cyclosporine- induced hypertension. J. Hypertens. 18, 927-933.

Thune, A., Jivegard, L., Pollard, H., Moreau, J., Schwartz, J. C., and Svanik, J. (1992). Location of enkephalinase and functional effects of [Leu5] enkephalin and inhibition of enkephalinase in the feline main pancreatic and bile duct sphincters. Clin. Sci. 82, 169-173.

Tormo, R., Polanco, I., Salazar-Lindo, E., and Goulet, O. (2008). Acute infectious diarrhoes in children: new insights in antisecretory treatment with racecadotril. Acta Paediatr. 97, 1008-1015.

Turck, D., Berard, H., Fretault, N., and Lecomte, J. M. (1999). Comparison of racecadotril and loperamide in children with acute diarrhoea. Aliment. Pharmacol. Ther. 13(Suppl. 6), 27-32.

Turvill, J., and Farthing, M. (1997). Enkephalins and enkephalinase inhibitors in intestinal fluid and electrolyte transport. Eur. J. Gastroenterol. Hepatol. 9, 877-880.

Uhlen, S., Toursel, F., and Gottrand, F. (2004). Treatment of acute diarrhea: prescription patterns by private practice pediatricians. Arch. Pediatr. 11, 903-907.

van Kemmel, F. M., Dubuc, I., bourdel, E., Fehrentz, J. A., Martinez, J., and Costentin, J. (1996). A C-terminal cyclic 8-13 neurotensin fragment analog appears less exposed to neprilysin when it crosses the bloodbrain barrier than the cerebrospinal fluid-brain barrier in mice. Neurosci. Lett. 217, 58-60.

Vetel, J. M., Berard, H., Fretault, N. and Lecomte, J. M. (1999). Comparison of racecadotril and loperamide in adults with acute diarrhoea. Aliment. Pharmacol. Ther. 13(Suppl. 6), 21-26.

Wang, H.-H., Shieh, M.-J., and Liao, K.-F. (2005). A blind, randomized comparison of racecadotril and loperamide for stopping acute diarrhea in adults. World J. Gastroenterol. 11, 1540-1543.

Wegner, M., Hirth-Dietrich, C., and Stasch, J. P. (1996). Role of neutral endopeptidase 24.11 in AV fistular rat model of heart failure. CVR 31, 891-898.

World Gastroenterology Association. (2008). World Gastroenterology Association practice guideline: acute diarrhea. Available at: http://www.omge. org/assets/downloads/en/pdf/ guidelines/01_acute_diarrhea.pdf

Wu, H. T., Chang, C. K., Cheng, K. C., Chang, C. H., Yeh, C. H., and Cheng, J. T. (2010). Increase of plasma insulin by racecadotril, an 
inhibitor of enkephalinase, in Wistar rats. Horm. Metab. Res. 42, 261-267.

$\mathrm{Xu}$, Y., Huang, J., Liu, F., Gao, S., and Guo, Q. (2007). Quantitative analysis of racecadotril metabolite in human plasma using a liquid chromatography/tandem mass spectrometry. J. Chromatogr. B Analyt. Technol. Biomed. Life Sci. 852, 101-107.

Ychou, M., Douillard, J. Y., Rougier, P., Adenis, A., Mousseau, M., Dufour, P., Wendling, J. L., Burki, F., Mignard, D., and Marty, M. (2000).
Randomized comparison of prophylactic antidiarrheal treatment versus non prophylactic antidiarrheal treatment in patients receiving CPT11 (irinotecan) for advanced 5-FUresistant colorectal cancer: an openlabel multicenter phase II study. Am. J. Clin. Oncol. 23, 143-148.

Zhou, Y., Luo, F., and Han, J. (1990). Enkephalinase inhibitors acetorphan and SCH34826 potentiate the analgesic effect of low frequency electroacupuncture in rats. Zhen $\mathrm{Ci}$ Yan Jiu 15, 310-314.
Conflict of Interest Statement: The authors declare that the research was conducted in the absence of any commercial or financial relationships that could be construed as a potential conflict of interest.

Received: 11 April 2012; accepted: 27 April 2012; published online: 30 May 2012.

Citation: Eberlin $M$, Mück $T$ and Michel MC (2012) A comprehensive review of the pharmacodynamics, pharmacokinetics, and clinical effects of the neutral endopeptidase inhibitor racecadotril. Front. Pharmacol. 3:93. doi: 10.3389/fphar.2012.00093

This article was submitted to Frontiers in Gastrointestinal Pharmacology, a specialty of Frontiers in Pharmacology. Copyright (c) 2012 Eberlin, Mück and Michel. This is an open-access article distributed under the terms of the Creative Commons Attribution Non Commercial License, which permits noncommercial use, distribution, and reproduction in other forums, provided the original authors and source are credited. 